Article

\title{
European Pesticide Tax Schemes in Comparison: An Analysis of Experiences and Developments
}

\author{
Thomas Böcker ${ }^{1}$ and Robert Finger ${ }^{2, *}$ \\ 1 Institute for Food and Resource Economics, University of Bonn, 53115 Bonn, Germany; \\ t.boecker@ilr.uni-bonn.de \\ 2 Agricultural Economics and Policy Group, ETH Zürich, 8092 Zurich, Switzerland \\ * Correspondence: rofinger@ethz.ch; Tel.: +41-44-632-53-92 \\ Academic Editors: Manuel González de Molina and Gloria Guzman \\ Received: 16 February 2016; Accepted: 11 April 2016; Published: 16 April 2016
}

\begin{abstract}
Policy measures are needed to reduce the risks associated with pesticides' application in agriculture, resulting in more sustainable agricultural systems. Pesticide taxes can be an important tool in the toolkit of policy-makers and are of increasing importance in European agriculture. However, little is known about the effects of such tax solutions and their impacts on the environment, farmers, and human health. We aim to fill this gap and synthesize experiences made in the European countries that have introduced pesticide taxes, i.e., France, Denmark, Norway, and Sweden. The major findings of our analysis are: (1) overall, the effectiveness of pesticide taxes is limited, but if a tax on a specific pesticide is high enough, the application and the associated risks will be reduced significantly; (2) in all countries, hoarding activities have been observed before a tax introduction or increase. Therefore, short-term effects of taxes are substantially smaller than long-term effects; (3) differentiated taxes are superior to undifferentiated taxes because fewer accompanying measures are required to reach policy goals; (4) tax scheme designs are not always in line with the National Action Plan targets. Low tax levels do not necessarily lead to a reduction of pesticide input and differentiated taxes do not necessarily lead to fewer violations of water residue limits.
\end{abstract}

Keywords: pesticide tax; national action plan; pesticide risk indicator; integrated pest management; Sweden; Denmark; Norway; France

\section{Introduction}

Policy measures are required in order to reduce the risks and negative external effects associated with pesticides' application in agriculture, resulting in more sustainable agricultural systems. Among others, pesticide taxes are an important tool in the toolkit of policy-makers and these taxes are of increasing importance. Hereby, pesticide taxes could foster the agro-ecological transition to integrated pest management practices via reducing pesticide use and substituting chemical inputs for biological and mechanical ones. Particularly with the implementation of National Action Plans (NAP) in Europe (Directive 2009/128/EC), pesticide taxes are an often discussed instrument in various European countries. For instance, a pesticide tax has recently been discussed intensively in Belgium, Switzerland, the Netherlands, and Germany [1-4]. Despite the fact that Sweden, Norway, Denmark, and France have introduced pesticide taxes, little is known about the effects of such tax solutions and its impacts on the environment, farmers, and human health. Thus, an overview and assessment of the different taxation schemes as well as experiences made is topical and of high relevance for both researchers and policy-makers.

Only few reviews on this topic have been provided [5-9]. This literature, however, has some limitations: firstly, the mentioned studies deliver outdated information due to changed policies. This limitation is particularly important because pesticide taxation policies have lately been revised 
completely in countries such as Denmark. A recent article by Lefebvre et al. [10] gives a short, up-to-date description of the different tax schemes, but an in-depth analysis was not in the scope of their paper. Secondly, descriptions and comparisons across all four countries that introduced a pesticide tax are lacking. Thirdly, none of these papers provides an assessment of the pesticide taxation schemes with respect to its effects on pesticide use and risk indicators as well as its coherence to the recent changes in NAPs. We aim to fill these gaps by presenting an up-to-date, detailed overview and assessment of the existing pesticide tax policies in Europe, including Sweden, Norway, Denmark, and France. Our assessment particularly focuses on the effects these policies have on farmers' pest management practices and the associated environmental and health risks. In addition, we summarize recent debates and depict future developments on pesticide taxes in other European countries. Moreover, the current fiscal pesticide policies are evaluated, also regarding their coherence to the targets of the recent NAPs of the four countries. To this end, different indicators are explained and analyzed.

The remainder of this article is structured as follows: in Section 2, we present frameworks for the evaluation of policies on pesticide use in general and pesticide taxation schemes especially. Next, fiscal instruments used in European countries are introduced and their effects on pesticide application and associated risks are assessed. Subsequently, the different fiscal policies are integrated in the presented framework for evaluation. Finally, the existing tax schemes are discussed and the conclusions are drawn.

\section{Methodology for Pesticide Policy Analysis}

During the 1990s, several studies evaluated political measures in order to reduce the pesticides' application and/or the environmental risk possibly related to the use of certain pesticides. In particular, the studies of Reus et al. [11], Oskam et al. [5], and Falconer [12] have presented theoretical foundations for the evaluation of economic instruments such as taxes for the reduction of environmental and human health risks associated with pesticides. The different criteria for the analysis are presented in Table 1. In all three studies, six criteria were applied. A combination of those criteria is also used in this article for the evaluation of existing pesticide tax schemes.

Table 1. Criteria used in pesticide policy evaluations.

\begin{tabular}{ccc}
\hline Reus et al. [11] (p. 64ff.) & Oskam et al. [5] (p. 42ff.) & Falconer [12] (p. 49) \\
\hline Effectiveness & Effectiveness & Effectiveness \\
Efficiency & Efficiency & Efficiency \\
Feasibility and maintainability & Enforceability & Maintainability \\
Polluter pays principle & Homogeneity & Polluter pays principle \\
Economic consequences & No income and property & Economic consequences \\
for farmers & rights disturbance & for farmers \\
Support among farmers & Acceptability & Ability to differentiate policies \\
\hline
\end{tabular}

Effectiveness refers to the ability of a political instrument to achieve its desired objective. Efficiency describes the costs of an instrument in relation to its objective achievement. Feasibility and maintainability, together with enforceability and maintainability, consider possibilities of control and fraud. The polluter pays principle stands for the justification of an instrument and the person responsible for pollution being charged. Private and societal benefits have to be balanced with private and societal costs (see e.g., $[13,14]$ ). The criteria homogeneity focuses on the additional financial burdens among farmers and their distribution. For example, fruit and vegetable growers, as well as potato growers, generally need to apply more pesticides than maize growers or grassland farmers and will, therefore, be taxed higher. In addition, the measure economic consequences for farmers and no income and property rights disturbance describe if losses occur due to a political instrument and how high those costs are. Finally, support among farmers and acceptability are overall criteria specifying to what extent policy 
measures are supported by farmers and their organizations. These criteria will be used to coherently assess the effects of the different pesticide taxation schemes.

In order to actually be able to measure the effectiveness of an instrument, the reduction objective needs to be specified. In principle, there are three possibilities to specify and measure such policy targets [15]. Firstly, pesticide use indicators measure the quantity of sold or applied active substances (AS). Those indicators are straightforward and the necessary data are easy to collect. For example, the treatment frequency measures the calculated number of pesticide applications under the assumption of a given standard area dose (SAD) [16]. Secondly, pesticide risk indicators aim to measure the load of a pesticide such as its risks on the environment or human health. It can consist of several sub-indicators which can be created e.g., by using hazard statements (H-phrases or R-phrases, respectively), bee hazards (e.g., in Germany the B-scores), the half-life, the deadly dose for non-target organisms, or measures like the concentration that affects $50 \%$ of the test organisms, or the concentration at which no effect between the control and test group can be observed. However, in order to measure the overall environmental load reduction due to the introduction of a policy instrument, very detailed data are necessary over a long period of time [16]. Thirdly, pesticide impact assessment systems aim to evaluate the effective impacts of pesticides on the environment, e.g., the influence of a pesticide on non-target organisms or biodiversity. In contrast to pesticide risk indicators, pesticide impact assessment systems are, to a larger extent, based on expert judgments than on chemical analyses [15].

The specific indicators used by the four different countries that introduced pesticide taxes are introduced in the subsequent sections.

\section{Fiscal Instruments Established in Europe}

When analyzing fiscal instruments, a differentiation between special taxes or levies on pesticides (use), the general taxation of pesticides (for example by the value added tax, VAT), and special charges on pesticides' registration has to be made. All instruments are in force in Europe. Fees for registration exist e.g., in the UK (Plant Protection Products (Fees and Charges) Regulations), in Germany (Pflanzenschutz-Gebührenverordnung), and in Sweden (Förordning (2013:63) om bekämpningsmedelsavgifter). Usually, those fees have to be paid by the developer and/or distributor. A VAT on pesticides is collected in all European countries, but the rate differs considerably: in most countries of the EU, the regular (i.e., not reduced) rate is charged ranging between $17 \%$ in Luxembourg and $27 \%$ in Hungary. As exceptions, Cyprus, Poland, Portugal, Slovenia, and Spain charge reduced VAT rates for pesticides [17]. Additionally, in Switzerland, a reduced VAT on pesticides of $2.5 \%$ exists (Art. 25 VAT Act). As these systems thus give quasi-subsidization to pesticides, adjustments towards full VAT taxation in Europe would be in line with current policy discussions on pesticide use. France has abandoned reduced VAT rates for pesticides in 2012, but now applies a combined system with the reduced rate on pesticides being allowed in organic farming and the regular rate on other pesticides (Art. 278 bis Code général des impôts). Until 2007, Finland had a special system, where the pesticides' producing or retailing sector was levied by a percentage rate to cover the registration and administration costs (with a total revenue of $€ 2$ million/year; [18]). Except for France, the major purpose of those two fiscal instruments (i.e., VAT and registration fees) is not to reduce pesticide risks or give incentives to adjust pesticide use.

In contrast, we focus on special taxation instruments that aim to especially reduce pesticide use or risks that are associated with pesticide use. In Table 2, possible combinations in the design of a pesticide tax are presented with regard to (i) the tax base and the tax rate of the charge; (ii) the imposition point; and (iii) the use or refunding of the revenues. The tax base for specific or for all pesticides can, for example, be a price, a mass/weight, or an indicator. Basically, the tax rate can be fix or differentiated and either a specific monetary value or a percentage. Note that for a wider organizational level (for example EU) also other combinations exist. The special taxations in the four countries will be described using some of the aspects of this framework. 
Table 2. Variations of taxation on pesticides on state level.

\begin{tabular}{|c|c|c|c|c|}
\hline \multicolumn{2}{|c|}{ Charge } & \multirow{2}{*}{ Imposition Point } & \multicolumn{2}{|c|}{ Use/Refunding of Revenues } \\
\hline Tax Base & Tax Rate & & Organization & Target \\
\hline $\begin{array}{l}\text { Wholesale price, } \\
\text { retail price, } \\
\text { active substances, } \\
\text { environmental risk, } \\
\text { human health risk }\end{array}$ & $\begin{array}{l}\text { Tariff level either } \\
\text { high, medium, or low, } \\
\text { percentage, } \\
\text { flat }\end{array}$ & $\begin{array}{l}\text { Industry, } \\
\text { wholesalers, } \\
\text { retailers, } \\
\text { farmers }\end{array}$ & $\begin{array}{l}\text { States, } \\
\text { federal states, } \\
\text { agricultural sector, } \\
\text { farmers involved, } \\
\text { other organizations }\end{array}$ & $\begin{array}{l}\text { State budget/deficit reduction, } \\
\text { Common Agricultural Policy, } \\
\text { direct payments/ha, } \\
\text { crop premiums, } \\
\text { innovation programs for industry } \\
\text { and agriculture, } \\
\text { supporting alternative techniques, } \\
\text { other }\end{array}$ \\
\hline
\end{tabular}

Reference: Following [6].

\subsection{Sweden}

As the first country worldwide, Sweden introduced a special flat tax on pesticides based on the volume sold in 1984. Initially, the tax was introduced with SEK 4/ kg AS and was increased stepwise to currently SEK 34/ kg AS $(\sim € 3.64 / \mathrm{kg})$ [19]. The last increase from SEK 30 to 34 took place at the beginning of August 2015 (§ $2 \mathrm{Lag}$ (1984:410) om skatt på bekämpningsmedel). In addition to the pesticide tax, a price regulation fee was charged between 1986 and 1992, which ranged between SEK 29-46/SAD. The fee was used for supporting the export of agricultural goods, but abolished in the course of the EU accession [7].

Until 1995, the financial means of the tax were used for agri-environmental programs aiming to reduce pesticide application and to promote integrated pest management [7]. After 1995, the revenues have been directly allocated to the state's treasury. The revenues are expected to be about SEK 70 million in 2015 and SEK 75 million in 2016 ( $€ 7.5$ million and $\sim € 8$ million, respectively) assuming that the sales quantity stays constant.

The first Swedish NAPs that were adopted during the 1980s focused on the reduction of overall pesticide use and application [20]. The present NAP still aims to reduce the use of pesticides, but more important is the reduction of the environmental risk that may be associated to the application of pesticides. These goals are, for example, the reduction of residues in surface water or food and the establishment of farming techniques that are less dependent on chemical pesticides [20]. Figure 1 shows that the absolute sales of AS in Sweden have been reduced by more than $50 \%$ since the 1980 s, even though statements about sold amounts AS have to be treated with caution, because the amount of AS does not reveal any information about environmental quality. In the last two decades, however, tax increases have not led to further reductions. In contrast, slight increases of several indicators are revealed in Figures 1 and 2. Regarding residues in water, detection of very high values (greater than $0.5 \mu \mathrm{g} / \mathrm{L}$ ) declined from 1987 to 2014. On the other hand, more residues between 0.1 and $0.5 \mu \mathrm{g} / \mathrm{L}$ were found [21]. Focusing on the share of wells with a minimum of one AS greater than $0.1 \mu \mathrm{g} / \mathrm{L}$, a reduction can be seen for the period 2010-2014 compared to the decade before [21]. Nevertheless, fewer samples were taken in this period, so that overall ambivalent effects can be observed. 


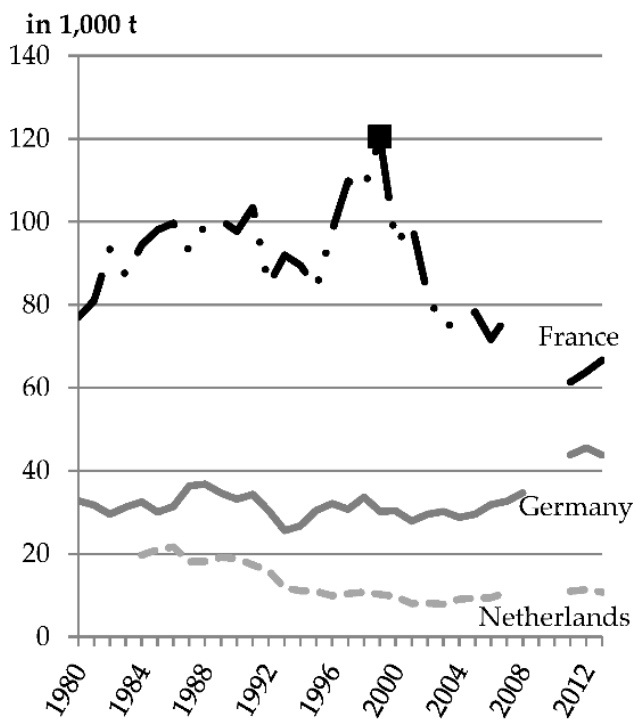

(a)

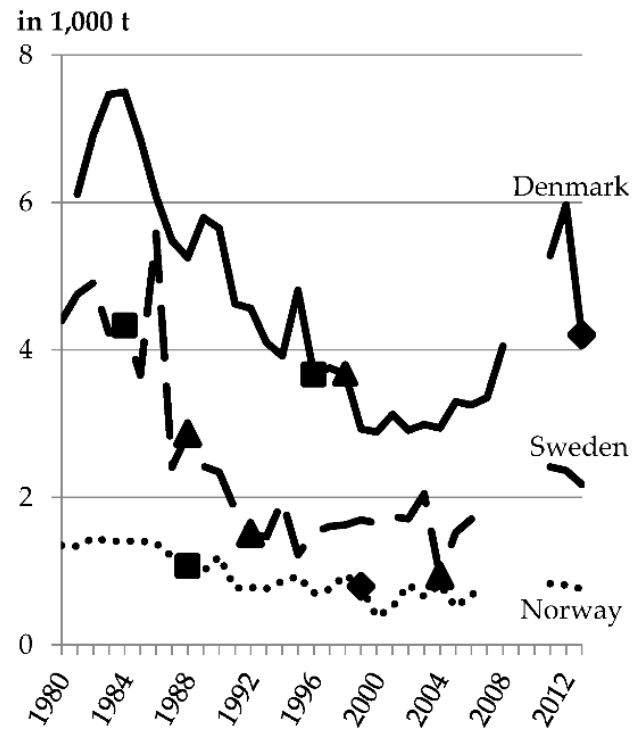

(b)

Figure 1. Sold active substances (1000 t) in selected European countries: (a) France, Germany, and the Netherlands; (b) Denmark, Sweden, and Norway. A " $\mathbf{\square}$ " symbolizes the introduction of a pesticide tax, a " $\mathbf{\Delta}$ " symbolizes a tax increase, and a " $\boldsymbol{\nabla}$ " a change of the tax scheme. Please note the different scales in the diagrams. Gaps in 2009 and 2010 are due to methodological changes in data collection. For Germany, until 1991, data are for West Germany. For Norway, until 1990, data are estimated according to [22]. Data reference: [23]. The data is provided in a supplementary file.

Figure 2 also shows the development of the aggregated Swedish pesticide risk indicator indexed to the year 1988 (index value of 100; disaggregation of the index is not possible). The health and environmental risk indicators are calculated by a point system and a set of scores. Among others, the environmental score, the application method score, the persistence score, and the operator toxicity score are used (see [24] for the exact calculation). Figure 2 indicates that especially the human health risk decreased sharply in the beginning of the 1990s and is now relatively constant at a level between $20 \%$ and $40 \%$ compared to the 1988 level. In contrast, the environmental risk indicator shows a less clear pattern with levels between $50 \%$ and $80 \%$ if compared to 1988 . Thus, positive developments coincide with the introduction of the tax. However, it is unlikely that the pesticide tax is the only determinant for the decrease of sales and risk. Other factors also contributed to these reductions. For instance, this development was caused by a consulting policy aiming at an integrated pest management, stricter permissions for the registration and application of pesticides, and the introduction of AS with low doses in the 1980s, e.g., by an increased application of seed dressing [24]. Overall, the pesticide tax was only a small part of the bundle of additional financial burdens that were introduced in the 1980s: a tax on artificial nitrogen fertilizer and cadmium/phosphorus was in place from 1984 until 2010 and the above mentioned price regulation charge was applied to fertilizers until 1992 as well [7,25]. Those taxes potentially contributed to a reduction of pesticides sold and their application as high fertilization rates increase pest and disease pressure and vice versa (for example a high-nitrogen fertilization might lead to a higher mildew and weed pressure [26]). Moreover, the value of the marginal product (the added value of one additional unit of input) decreases by reducing fertilizer input and thus causes lower optimal pesticide application levels. However, since both political instruments were introduced at the same time, it is difficult to identify the major influencing factor. 


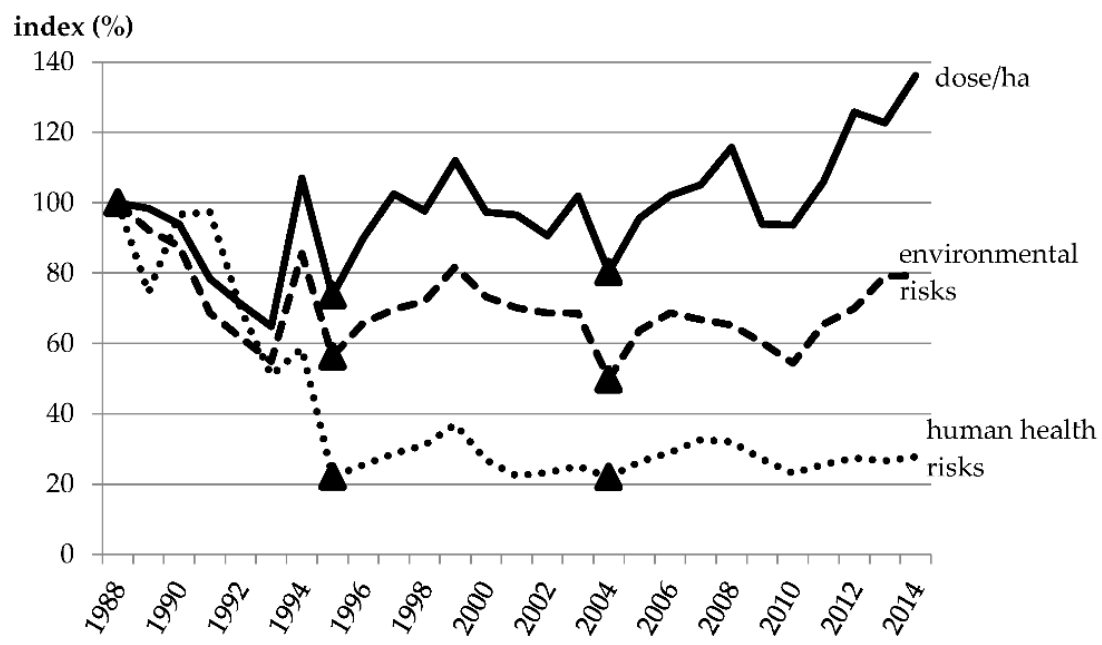

Figure 2. Development of Swedish pesticide risk indicator with respect to environmental and human health risks. In addition, the average dose/ha is shown as an index. The pesticide risk indicator is

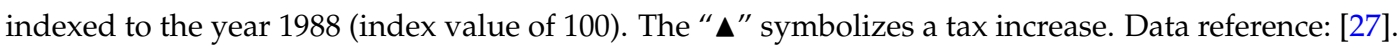
The data is provided in a supplementary file.

\subsection{Norway}

As the second European country, Norway introduced a tax on pesticides in 1988. First, the tax was designed as an ad valorem tax as a percentage of the import value [22]. In 1999, the tax was changed into a differentiated scheme and now consists of a base rate and an additional rate. Pesticides are sorted into seven different categories. The base rate is a tax per ha, which is calculated by multiplying NOK $25 /$ ha times a specific factor being associated with the category of a certain pesticide (ranging from 0.5 to 150 ). The categories are assessed by two sub-categories: (i) risks for human health and (ii) environmental risks. All pesticides for professional use are tested according to several criteria and then categorized in a low, medium, or high risk ( $\S 28$ Forskrift om plantevernmidler). The human health-criterion is based on the intrinsic properties (according to R-phrases) and the exposure during application and mixing [28]. The environmental criterion is compounded by eight sub-scores. They measure effects on earthworms, on bees and other arthropods, on birds, on aquatic organisms, the leaching potential, the persistence, the bioaccumulation, and the formulation type [28]. The categorization of the factors can be seen in Table 3. The additional rate is calculated via the SAD (Norwegian: normert arealdose NAD). The SAD refers to the highest possible application dose (in $\mathrm{ml}$ or $\mathrm{g}$ per ha), which is recommended for the main crop in the field of application ([22]; for the product list see [29]). Using the example of liquid products, the final tax is calculated as follows:

$$
\begin{gathered}
\text { tax in } \frac{\mathrm{NOK}}{l}=\text { base rate } \times \text { additional rate } \\
=\frac{\mathrm{NOK} 25}{\mathrm{ha}} \times \text { factor }_{\mathrm{i}} \times \frac{1000 \frac{\mathrm{mL}}{\mathrm{L}}}{\mathrm{SAD} \frac{\mathrm{mL}}{\mathrm{ha}}}
\end{gathered}
$$

Table 3. Norwegian factor categorization for base rate calculation.

\begin{tabular}{ccccccccc}
\hline \multicolumn{2}{c}{ Tax Category i } & $\mathbf{1}$ & $\mathbf{2}$ & $\mathbf{3}$ & $\mathbf{4}$ & $\mathbf{5}$ & $\mathbf{6}$ \\
\hline $\begin{array}{c}\text { Pesticide } \\
\text { characteristics }\end{array}$ & $\begin{array}{c}\text { Human health } \\
\text { risks }\end{array}$ & $\begin{array}{c}\text { Both } \\
\text { risks } \\
\text { low }\end{array}$ & $\begin{array}{c}\text { One low } \\
\text { and one } \\
\text { medium } \\
\text { risk } \\
\text { risks }\end{array}$ & $\begin{array}{c}\text { One low and } \\
\text { one high risk } \\
\text { or both risks } \\
\text { medium }\end{array}$ & $\begin{array}{c}\text { One } \\
\text { medium } \\
\text { and one } \\
\text { high risk }\end{array}$ & $\begin{array}{c}\text { Both } \\
\text { risks } \\
\text { high }\end{array}$ & $\begin{array}{c}\text { Concentrated } \\
\text { products for } \\
\text { hobby use }\end{array}$ & $\begin{array}{c}\text { Ready-to-use } \\
\text { products for } \\
\text { hobby use }\end{array}$ \\
\hline Factor i (* NOK 25/ha) & 0.5 & 3 & 5 & 7 & 9 & 50 \\
\hline Tax (NOK/ha) & 12.5 & 75 & 125 & 175 & 225 & 1250 & 3750 \\
\hline
\end{tabular}


Products that are allowed in organic farming are exempted from the tax (\$§ 27-28 Forskrift om plantevernmidler). Producers and importers have to pay the tax to the authorities. The government estimates to earn about NOK 50 million in 2015 ( $€ 5.8$ million) [31]. An in-depth analysis of the tax scheme was presented by Spikkerud [22]. There are various disadvantages associated with such an assessment that is based on different categories. For instance, products, which are close to the threshold at several criteria, are classified, e.g., as low-risk products. In contrast, products that exceed the threshold value for one criterion but are far below the threshold for the other criteria are categorized as high- or medium-risk pesticides. Therefore, relatively large tax differences can occur for products that may actually differ little in their riskiness to human health or the environment [22]. Furthermore, the SAD measure is problematic because a low SAD leads to a higher taxation and vice versa. The underlying assumption is that pesticides with a high application dose are less risky (even though environmental toxicity is additionally accounted for in specific factors). In total, this could lead to a higher total application of pesticides, while the human health and environmental risk decreases [22]. Finally, the usage of the maximum recommended dose for a specific main field of application is critical. For some pesticides, this determination is not easily feasible. For instance, for vegetables and fruits different doses are usually recommended per crop type and per production system (for example field-grown vs greenhouse production) so that probably an incorrect or inappropriate tax base is used [22].

The quantity of pesticides' sold reduced slightly since the introduction of the tax (Figure 1). After changing the tax to a differentiated scheme in 1999, the sold quantity stayed constant except for a break shortly after the change. One reason for the latter might be that the taxation of some low risk products actually was reduced when switching to a differentiated tax scheme since before already an ad valorem tax on pesticides was established. The greater popularity of no-till cultivation and the accompanied application of glyphosate also contributed to the non-reduction of the sales quantity of pesticides [32]. The two Norwegian NAPs from 1998 to 2008 aimed to reduce the health and environmental risk of pesticides by $50 \%$ [33]. The pesticide risk indicator being used for the assessment of this target is divided into a human health risk indicator and an environmental risk indicator [34]. Analyzing those two pesticide risk indicators, a small to medium reduction can be observed (Figure 3, and [30]). The figure presents the development of the annual sales data of the retailers and the development of the pesticide risk indicator. The marked peaks represent large increases of pesticides sold in advance of the introduction or of changes in the tax scheme. Note that the retailers' behavior is reflected more than the farmers' behavior, although it is likely that also farmers hoarded pesticides to save tax payments in future periods. For this reason, the human health and environmental criteria should only be analyzed in the long-term. Furthermore, Strøm Prestvik et al. [30] observe a decline in the range of highly taxed products (categories 4 and 5) and an increase in the range of category 1 and 2 pesticides. In 2014, no products of the tax category 5 were registered in Norway [29]. At the single crop level, Strøm Prestvik et al. [30] show that in 2011, hardly any fungicides of category 4 are used anymore in cereal production and fungicides of category 3 have been substituted by products of category 1 or 2 in potato production. Along these lines, in 2001, almost no category 1 products were applied, but they were used in 50\% of the applications in 2011 [30]. However, due to the hoarding activities of farmers (before 1999 at the change of the tax scheme and before 2005 due to minor revisions of the scheme; Figure 3), it took several years until the tax became effective and a more constant reduction of the pesticide risk indicator could be observed. The latest NAP was in place from 2010 to 2014, but did not specify any concrete reduction targets like the two preceding NAPs. Rather, it was aimed to decrease the dependency of chemical pesticides and to increase the share of farmers that produce according to integrated farming practices specified in the good agricultural practice [35]. More specifically, a particular goal is to avoid violations of threshold values of standards for groundwater, surface water, and food. Regarding residues on food products, however, most cases of threshold violations occur in products that are imported [36]. Moreover, the recent developments show indeed that fewer violations of threshold values could be observed across space (for different regions) and across various 
AS [37]. However, the analyses show that many violations already declined before introducing the differentiated tax. Measures that contributed to this are for example stricter application guidelines and better spraying techniques to avoid point source contamination and drift. Additionally, the overall number of detected residues (i.e., not exceeding the threshold) has not decreased [38] and challenges with newer AS appear (e.g., increasing residues of prothioconazole, imidacloprid, and aclonifen [37]). Therefore, no clear pattern is observable whether the tax contributed to these improvements. Note that integrated pest management is also mandatory for countries in the EU since 2009 due to the Directive 2009/128/EC (to achieve the sustainable use of pesticides) and the Regulation (EC) No. 1107/2009 (concerning the placing of plant protection products on the market).

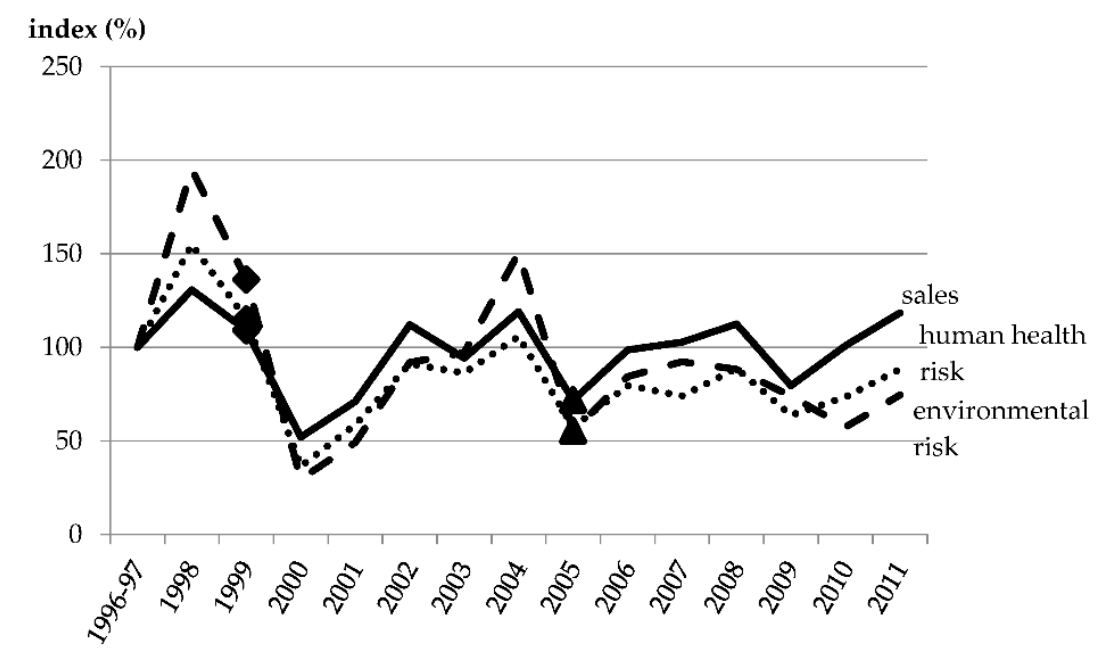

Figure 3. Development of the Norwegian pesticide risk indicator with respect to environmental and human health risks as well as total annual sales based on retailers' sales data. The average of 1996 and 1997 is used as index base (index value of 100). A " $\mathbf{}$ "symbolizes a change of the tax scheme and a " $\mathbf{\Delta}$ " a tax increase. Data reference: Statistics Norway and the Norwegian Food Safety Authority [39]. The data is provided in a supplementary file.

\subsection{Denmark}

In 1996, Denmark introduced an ad valorem pesticide tax on the highest existing wholesale price. This tax was differentiated by the pesticide's category. For example, for insecticides a tax rate of 35\% was charged and for herbicides, fungicides, and growth regulators a rate of $25 \%$. In 2013, the tax scheme was changed into a more differentiated one, because the treatment frequency (measured by the AS' sales, see also Figure 1) and the pesticides' load re-increased [40]. Similar to other countries, the latest increase in AS' sales have been induced by the larger relevance of no till practices and the associated application of glyphosate [32]. Moreover, high output prices and the corresponding higher value of marginal product contributed to increases in pesticide use [41]. In the new tax scheme, each single pesticide product receives its specific tax rate (LBK $\mathrm{nr} 232$ Bekendtgørelse af lov om afgift af bekæmpelsesmidler as at 26 February 2015). Note that the old scheme is kept for biocides but with increased tax rates of $40 \%$ on insecticides (before: $35 \%$ ) and $30 \%$ on herbicides and fungicides (before: $25 \%$ ). The new differentiated tax for pesticides is a combination of a pesticide use and a pesticide risk indicator and is calculated as follows (presented for a liquid product):

$$
\begin{aligned}
& \text { tax in } \frac{\text { DKK }}{l}=\text { exposition tax }+ \text { toxicity tax } \\
& =\frac{\text { DKK50 }}{\operatorname{kg~AS}} \times X \frac{\mathrm{kg} \mathrm{AS}}{1}+\sum_{\mathrm{i}=1}^{3} \frac{\text { DKK107 }}{1} \times \text { factor }_{\mathrm{i}} \mathrm{L}
\end{aligned}
$$

The exposition tax takes into account the amount of AS of the pesticide product (X kg AS/l) and multiplies it times DKK 50. The toxicity tax is calculated with the help of a pesticide risk indicator, 
the so called Pesticide Load Indicator. This indicator comprises of three different factors (categories) measuring the environmental load of a pesticide: (1) environmental toxicity load; (2) environmental fate and behavior load; and (3) human health load. The Danish scheme, thus, extends the scope of the Norwegian scheme by adding the dimension of environmental fate. The load score of each factor is defined by several sub-indicators and the score is then multiplied by DKK 107. The "human health load" is assessed by the R-phrases of a plant protection product and by the exposure during application [40,42]. The "environmental fate load" is measured by the AS' degradability, potential for bioaccumulation, and its leaching potential. "Environmental toxicity load" consists of sub-scores for birds, mammals, fish, daphnia, algae, aquatic plants, earthworms, and bees. Additionally, there is a higher tax rate for seed treatment products at the factor "environmental effects" [40,42].

The tax introduction was accompanied with the implementation of measures to compensate farmers. In particular, the property tax on agricultural land was reduced by DKK 62-72/ha, depending on the county [7]. Moreover, tax revenues were used to support organic farming and for administrative services $[7,43,44]$. According to the current legislation, the revenues of the tax first flow into the states treasury ( $\$ 1$ LBK nr 232) but are then returned for agricultural and environmental purposes. In 2013, these revenues were DKK 659 million ( $0.23 \%$ of the state's budget; $\sim € 88.4$ million). For 2015, revenues of DKK 600 million are estimated [45]. From that, DKK 250 million are designated for the agricultural fund (promilleafgiftsfonden for landbrug), which supports different measures concerning the Danish agriculture [46]. About DKK 175 million are destined for green growth measures—of which some are related to the NAP_and about DKK 75 million are used for administrative purposes. The current Danish NAP for the period 2013 until 2015 aims to reduce the total load of pesticides by $40 \%$ until the end of 2015 [47]. The reduction is measured with the Pesticide Load Indicator. The differentiated tax has a main role in achieving this objective.

Due to the short time span since the implementation of the new tax scheme, no conclusion can be drawn whether the objective is fulfilled. However, the new design of the Danish tax implies large burdens for some products. The heterogeneity of tax levels is higher compared to other taxation regimes. For example, the insecticide Cythrin 500 containing $500 \mathrm{~g} / \mathrm{L}$ cypermethrin was taxed with DKK 7709/L (DKK 617/ha, $€$ 83/ha respectively at a recommended dose for rapeseed of $0.08 \mathrm{~L} / \mathrm{ha}$ ) and the insecticide Gamma C containing $60 \mathrm{~g} / \mathrm{L}$ gamma-cyhalothrin is taxed with DKK 6009/L (DKK $361 /$ ha, $\sim € 48 /$ ha, respectively, at a recommended dose for rapeseed of $0.06 \mathrm{~L} / \mathrm{ha}$; see Table 4 for further examples). Even though allowing more flexibility than bans of pesticides, high taxation levels could lead to the disappearance of those highly hazardous products (mostly insecticides) from the market. Critics are concerned that, as a consequence, problems of resistances might be enlarged [48], which could lead to a more intense application of other, cheaper pesticides. It is, therefore, possible that a single application leads to a lower environmental load under the new tax scheme, but when summing up all applications, a load similar to the one under the old tax scheme or without tax is reached. In order to counter this effect, one opportunity would be to simplify the pesticide registration process, but since it is an EU policy matter, this is not easily possible. In contrast, the breeding and use of more resistant varieties is a positive side effect of the tax and would support the reduction of pesticide use. Further criticism indicates that farmers face extra burdens and have become less competitive compared to other European producers [41,48,49]. However, this depends on the crop that is produced since some pesticides are now burdened lower compared to the old tax scheme [43]. 
Table 4. Comparison of the taxation of different pesticides (selection). ${ }^{1}$ Hectare cost values were calculated in all countries based on the Norwegian SAD to guarantee comparison of the results. It could be that the SAD in Norway differs in the other countries. The different pesticide products were selected on the basis of: (1) availability in Norway; (2) relevance of product; (3) different categories of products (risk and use class); and (4) availability in other countries.

\begin{tabular}{|c|c|c|c|c|c|c|c|c|c|c|}
\hline \multirow{2}{*}{ Type $^{2}$} & \multirow[b]{2}{*}{ Product Name (Depending on Country) } & \multirow[b]{2}{*}{ Active Substance } & \multicolumn{2}{|c|}{ Sweden } & \multicolumn{2}{|c|}{ Norway } & \multicolumn{2}{|c|}{ Denmark } & \multicolumn{2}{|c|}{ France } \\
\hline & & & $\begin{array}{c}€ / \mathrm{kg} \text { or } \mathrm{L} \\
(\mathrm{SEK} / \mathrm{kg} \text { or } \mathrm{L})\end{array}$ & $\begin{array}{c}\text { E/ha } \\
\text { (SEK/ha) }\end{array}$ & $\begin{array}{c}€ / \mathrm{kg} \text { or } \mathrm{L} \\
(\mathrm{NOK} / \mathrm{kg} \text { or } \mathrm{L})\end{array}$ & $\begin{array}{c}\text { €/ha } \\
\text { (NOK/ha) }\end{array}$ & $\begin{array}{c}\epsilon / \mathrm{kg} \text { or } \mathrm{L} \\
(\mathrm{DKK} / \mathrm{kg} \text { or } \mathrm{L})\end{array}$ & $\begin{array}{c}€ / \text { ha } \\
\text { (DKK/ha) }\end{array}$ & $€ / \mathrm{kg}$ or $\mathrm{L}$ & f/ha \\
\hline $\mathrm{F}$ & $\begin{array}{l}\text { Acanto }{ }^{\circledR} 250 \mathrm{SC} / \text { Aproach } \circledast \\
(\mathrm{SAD} \text { in } \mathrm{NO}=1000 \mathrm{~mL})\end{array}$ & Picoxystrobin $250 \mathrm{~g} / \mathrm{L}$ & $\begin{array}{c}0.91 \\
(8.50)\end{array}$ & $\begin{array}{l}0.91 \\
(8.50)\end{array}$ & $\begin{array}{c}14.45 \\
(125.00)\end{array}$ & $\begin{array}{c}14.45 \\
(125.00)\end{array}$ & $\begin{array}{c}13.54 \\
(101.00)\end{array}$ & $\begin{array}{l}13.54 \\
(101.00)\end{array}$ & 0.50 & 0.50 \\
\hline $\mathrm{F}$ & $\begin{array}{l}\text { Amistar }{ }^{\circledR} \\
(\mathrm{SAD} \text { in } \mathrm{NO}=1000 \mathrm{~mL} / \mathrm{ha})\end{array}$ & Azoxystrobin $250 \mathrm{~g} / \mathrm{L}$ & $\begin{array}{c}0.91 \\
(8.50)\end{array}$ & $\begin{array}{c}0.91 \\
(8.50)\end{array}$ & $\begin{array}{c}8.67 \\
(75.00)\end{array}$ & $\begin{array}{c}8.67 \\
(75.00)\end{array}$ & $\begin{array}{c}5.50 \\
(41.00)\end{array}$ & $\begin{array}{c}5.50 \\
(41.00)\end{array}$ & 1.28 & 1.28 \\
\hline $\mathrm{F}$ & $\begin{array}{l}\text { Comet }{ }^{\circledR} \\
(\mathrm{SAD} \text { in } \mathrm{NO}=1000 \mathrm{~g} / \mathrm{ha})\end{array}$ & Pyraclostrobin $250 \mathrm{~g} / \mathrm{L}$ & $\begin{array}{c}0.91 \\
(8.50)\end{array}$ & $\begin{array}{c}0.91 \\
(8.50)\end{array}$ & $\begin{array}{c}8.67 \\
(75.00)\end{array}$ & $\begin{array}{c}8.67 \\
(75.00)\end{array}$ & $\begin{array}{l}13.00 \\
(97.00)\end{array}$ & $\begin{array}{l}13.00 \\
(97.00)\end{array}$ & 1.28 & 1.28 \\
\hline $\mathrm{F}$ & $\begin{array}{l}\text { Stereo®312.5 EC } \\
(\mathrm{SAD} \text { in NO = } 1500 \mathrm{~mL} / \mathrm{ha})\end{array}$ & $\begin{array}{l}\text { Cyprodinil } 250 \mathrm{~g} / \mathrm{L} \\
\text { Propiconazole } 62.5 \mathrm{~g} / \mathrm{L}\end{array}$ & $\begin{array}{c}1.14 \\
(10.63)\end{array}$ & $\begin{array}{c}1.71 \\
(15.94)\end{array}$ & $\begin{array}{c}9.63 \\
(83.33)\end{array}$ & $\begin{array}{c}14.45 \\
(125.00)\end{array}$ & $\begin{array}{c}20.91 \\
(156.00)\end{array}$ & $\begin{array}{l}31.37 \\
(234.00)\end{array}$ & - & - \\
\hline $\mathrm{F}$ & $\begin{array}{l}\text { Switch }{ } 62.5 \mathrm{WG} \\
(\mathrm{SAD} \text { in } \mathrm{NO}=500 \mathrm{~g} / \mathrm{ha})\end{array}$ & $\begin{array}{l}\text { Cyprodinil } 375 \mathrm{~g} / \mathrm{kg} \\
\text { Fludioxonil } 250 \mathrm{~g} / \mathrm{kg}\end{array}$ & $\begin{array}{c}3.64 \\
(34.00)\end{array}$ & $\begin{array}{c}1.82 \\
(17.00)\end{array}$ & $\begin{array}{l}28.90 \\
(250.00)\end{array}$ & $\begin{array}{c}14.45 \\
(125.00)\end{array}$ & $\begin{array}{c}14.34 \\
(107.00)\end{array}$ & $\begin{array}{c}7.17 \\
(53.50)\end{array}$ & 1.25 & 0.63 \\
\hline $\mathrm{F}$ & $\begin{array}{l}\text { Talius }{ }^{\circledR} \\
(\mathrm{SAD} \text { in } \mathrm{NO}=250 \mathrm{~mL} / \mathrm{ha})\end{array}$ & Proquinazid $200 \mathrm{~g} / \mathrm{L}$ & - & - & $\begin{array}{l}57.80 \\
(500.00)\end{array}$ & $\begin{array}{c}14.45 \\
(125.00)\end{array}$ & - & - & 1.02 & 0.26 \\
\hline GR & $\begin{array}{l}\text { Moddus }{ }^{\circledR M} / \text { Moxa }{ }^{\circledR} \\
(\mathrm{SAD} \text { in } \mathrm{NO}=400 \mathrm{~mL} / \mathrm{ha})\end{array}$ & Trinexapac-ethyl $250 \mathrm{~g} / \mathrm{L}$ & $\begin{array}{c}0.91 \\
(8.50)\end{array}$ & $\begin{array}{c}0.36 \\
(3.40)\end{array}$ & $\begin{array}{c}3.61 \\
(31.25)\end{array}$ & $\begin{array}{c}1.45 \\
(12.50)\end{array}$ & $\begin{array}{c}4.42 \\
(33.00)\end{array}$ & $\begin{array}{c}1.77 \\
(13.20)\end{array}$ & 0.50 & 0.20 \\
\hline $\mathrm{H}$ & $\begin{array}{l}\text { Ally®Class } 50 \text { WG/AlliéßExpress } \\
(\mathrm{SAD} \text { in } \mathrm{NO}=50 \mathrm{~g} / \mathrm{ha} \text { ) }\end{array}$ & $\begin{array}{l}\text { Metsulfuron-methyl } 100 \mathrm{~g} / \mathrm{kg} \\
\text { Carfentrazone-ethyl } 400 \mathrm{~g} / \mathrm{kg}\end{array}$ & $\begin{array}{c}1.82 \\
(17.00)\end{array}$ & $\begin{array}{l}0.09 \\
(0.85)\end{array}$ & $\begin{array}{l}28.90 \\
(250.00)\end{array}$ & $\begin{array}{c}1.45 \\
(12.50)\end{array}$ & - & - & 1.00 & 0.05 \\
\hline $\mathrm{H}$ & $\begin{array}{l}\text { Basagran } \circledast S G \\
(\mathrm{SAD} \text { in } \mathrm{NO}=1600 \mathrm{~g} / \mathrm{ha})\end{array}$ & Bentazone $870 \mathrm{~g} / \mathrm{kg}$ & $\begin{array}{c}3.17 \\
(29.58)\end{array}$ & $\begin{array}{c}5.07 \\
(47.33)\end{array}$ & $\begin{array}{c}5.42 \\
(46.88)\end{array}$ & $\begin{array}{c}8.67 \\
(75.00)\end{array}$ & $\begin{array}{l}15.15 \\
(113.00)\end{array}$ & $\begin{array}{c}24.24 \\
(180.80)\end{array}$ & 1.74 & 2.78 \\
\hline $\mathrm{H}$ & $\begin{array}{l}\text { Boxer }{ }^{\circledR} \\
(\mathrm{SAD} \text { in } \mathrm{NO}=5000 \mathrm{~mL} / \mathrm{ha})\end{array}$ & Prosulfocarb $800 \mathrm{~g} / \mathrm{L}$ & $\begin{array}{c}2.91 \\
(27.20)\end{array}$ & $\begin{array}{c}14.56 \\
(136.00)\end{array}$ & $\begin{array}{c}2.89 \\
(25.00)\end{array}$ & $\begin{array}{c}14.45 \\
(125.00)\end{array}$ & $\begin{array}{c}16.62 \\
(124.00)\end{array}$ & $\begin{array}{l}83.11 \\
(620.00)\end{array}$ & - & - \\
\hline $\mathrm{H}$ & $\begin{array}{l}\text { Express }{ }^{\circledR G o l d} \mathrm{SX} / \mathrm{CDQ}{ }^{\circledR S X} \\
(\mathrm{SAD} \text { in } \mathrm{NO}=34 \mathrm{~g} / \mathrm{ha})\end{array}$ & $\begin{array}{l}\text { Tribenuron-methyl } 222.2 \mathrm{~g} / \mathrm{kg} \\
\text { Metsulfuron-methyl } \\
111.1 \mathrm{~g} / \mathrm{kg}\end{array}$ & - & - & $\begin{array}{c}42.50 \\
(367.65)\end{array}$ & $\begin{array}{c}1.45 \\
(12.50)\end{array}$ & $\begin{array}{c}16.76 \\
(125.00)\end{array}$ & $\begin{array}{c}0.57 \\
(4.25)\end{array}$ & - & - \\
\hline $\mathrm{H}$ & $\begin{array}{l}\text { Gratil@75 WG } \\
\text { (SAD in NO = } 60 \mathrm{~g} / \mathrm{ha} \text { ) }\end{array}$ & Amidosulfuron $750 \mathrm{~g} / \mathrm{kg}$ & $\begin{array}{c}2.73 \\
(25.50)\end{array}$ & $\begin{array}{l}0.16 \\
(1.53)\end{array}$ & $\begin{array}{c}144.51 \\
(1250.00)\end{array}$ & $\begin{array}{c}8.67 \\
(75.00)\end{array}$ & - & - & 1.50 & 0.09 \\
\hline $\mathrm{H}$ & $\begin{array}{l}\text { HussarßOD } \\
(\mathrm{SAD} \text { in } \mathrm{NO}=100 \mathrm{~mL} / \mathrm{ha})\end{array}$ & Iodosulfuron $100 \mathrm{~g} / \mathrm{L}$ & - & - & $\begin{array}{l}14.45 \\
(125.00)\end{array}$ & $\begin{array}{c}1.45 \\
(12.50)\end{array}$ & $\begin{array}{c}6.30 \\
(47.00)\end{array}$ & $\begin{array}{c}0.63 \\
(4.70)\end{array}$ & - & - \\
\hline $\mathrm{H}$ & $\begin{array}{l}\text { MaisTer } \\
(\mathrm{SAD} \text { in } \mathrm{NO}=150 \mathrm{~g} / \mathrm{ha})\end{array}$ & $\begin{array}{l}\text { Foramsulfuron } 300 \mathrm{~g} / \mathrm{kg} \\
\text { Iodosulfuron } 10 \mathrm{~g} / \mathrm{kg}\end{array}$ & $\begin{array}{c}1.13 \\
(10.54)\end{array}$ & $\begin{array}{c}0.17 \\
(1.58)\end{array}$ & $\begin{array}{c}9.63 \\
(83.33)\end{array}$ & $\begin{array}{c}1.45 \\
(12.50)\end{array}$ & $\begin{array}{c}11.13 \\
(83.00)\end{array}$ & $\begin{array}{c}1.67 \\
(12.45)\end{array}$ & - & - \\
\hline
\end{tabular}


Table 4. Cont.

\begin{tabular}{|c|c|c|c|c|c|c|c|c|c|c|}
\hline \multirow{2}{*}{ Type $^{2}$} & \multirow[b]{2}{*}{ Product Name (Depending on Country) } & \multirow[b]{2}{*}{ Active Substance } & \multicolumn{2}{|c|}{ Sweden } & \multicolumn{2}{|c|}{ Norway } & \multicolumn{2}{|c|}{ Denmark } & \multicolumn{2}{|c|}{ France } \\
\hline & & & $\begin{array}{c}€ / \mathrm{kg} \text { or } \mathrm{L} \\
(\mathrm{SEK} / \mathrm{kg} \text { or } \mathrm{L})\end{array}$ & $\begin{array}{c}\text { E/ha } \\
\text { (SEK/ha) }\end{array}$ & $\begin{array}{c}€ / \mathrm{kg} \text { or } \mathrm{L} \\
(\mathrm{NOK} / \mathrm{kg} \text { or } \mathrm{L})\end{array}$ & $\begin{array}{c}€ / \text { ha } \\
\text { (NOK/ha) }\end{array}$ & $\begin{array}{c}\epsilon / \mathrm{kg} \text { or } \mathrm{L} \\
(\mathrm{DKK} / \mathrm{kg} \text { or } \mathrm{L})\end{array}$ & $\begin{array}{c}\text { €/ha } \\
\text { (DKK/ha) }\end{array}$ & $€ / \mathrm{kg}$ or $\mathrm{L}$ & f/ha \\
\hline $\mathrm{H}$ & $\begin{array}{l}\text { Roundup } \circledast \text { Max } / \text { Roundup } ® 680 \\
(\mathrm{SAD} \text { in } \mathrm{NO}=2000 \mathrm{~g} / \mathrm{ha})\end{array}$ & Glyphosate $680 \mathrm{~g} / \mathrm{kg}$ & $\begin{array}{c}2.48 \\
(23.12)\end{array}$ & $\begin{array}{c}4.95 \\
(46.24)\end{array}$ & $\begin{array}{c}0.72 \\
(6.25)\end{array}$ & $\begin{array}{c}1.45 \\
(12.50)\end{array}$ & $\begin{array}{c}9.79 \\
(73.00)\end{array}$ & $\begin{array}{c}19.57 \\
(146.00)\end{array}$ & 1.36 & 2.72 \\
\hline I & $\begin{array}{l}\text { Biscaya } ₫ O D \\
(\mathrm{SAD} \text { in } \mathrm{NO}=400 \mathrm{~mL} / \mathrm{ha})\end{array}$ & Thiacloprid $240 \mathrm{~g} / \mathrm{L}$ & $\begin{array}{c}0.87 \\
(8.16)\end{array}$ & $\begin{array}{c}0.35 \\
(3.26)\end{array}$ & $\begin{array}{c}36.13 \\
(312.50)\end{array}$ & $\begin{array}{c}14.45 \\
(125.00)\end{array}$ & $\begin{array}{c}16.09 \\
(120.00)\end{array}$ & $\begin{array}{c}6.43 \\
(48.00)\end{array}$ & 1.22 & 0.49 \\
\hline I & $\begin{array}{l}\text { Calypso®480 SC } \\
(\mathrm{SAD} \text { in } \mathrm{NO}=200 \mathrm{~mL} / \mathrm{ha})\end{array}$ & Thiacloprid $480 \mathrm{~g} / \mathrm{L}$ & $\begin{array}{c}1.75 \\
(16.32)\end{array}$ & $\begin{array}{c}0.35 \\
(3.26)\end{array}$ & $\begin{array}{l}101.16 \\
(875.00)\end{array}$ & $\begin{array}{c}20.23 \\
(175.00)\end{array}$ & - & - & 2.45 & 0.49 \\
\hline I & $\begin{array}{l}\text { Confidor®70 WG } \\
\text { (SAD in NO = } 200 \mathrm{~g} / \mathrm{ha})\end{array}$ & Imidacloprid $700 \mathrm{~g} / \mathrm{kg}$ & $\begin{array}{c}2.55 \\
(23.80)\end{array}$ & $\begin{array}{c}0.51 \\
(4.76)\end{array}$ & $\begin{array}{c}7.23 \\
(62.50)\end{array}$ & $\begin{array}{c}1.45 \\
(12.50)\end{array}$ & $\begin{array}{c}5.23 \\
(39.00)\end{array}$ & $\begin{array}{c}1.05 \\
(7.80)\end{array}$ & - & - \\
\hline I & $\begin{array}{l}\text { Karate }{ }^{5} \mathrm{CS} / \text { Karate }{ }^{\circledR} \text { Foret } \\
(\mathrm{SAD} \text { in } \mathrm{NO} 150 \mathrm{~mL} / \mathrm{ha})\end{array}$ & Lambda- cyhalothrin $50 \mathrm{~g} / \mathrm{L}$ & $\begin{array}{c}0.18 \\
(1.70)\end{array}$ & $\begin{array}{c}0.03 \\
(0.26)\end{array}$ & $\begin{array}{c}96.34 \\
(833.33)\end{array}$ & $\begin{array}{c}14.45 \\
(125.00)\end{array}$ & - & - & 0.26 & 0.04 \\
\hline I & $\begin{array}{l}\text { Steward } ₫ 30 \mathrm{WG} \\
(\mathrm{SAD} \text { in } \mathrm{NO}=250 \mathrm{~g} / \mathrm{ha})\end{array}$ & Indoxacarb $300 \mathrm{~g} / \mathrm{kg}$ & $\begin{array}{c}1.09 \\
(10.20)\end{array}$ & $\begin{array}{c}0.27 \\
(2.55)\end{array}$ & $\begin{array}{c}57.80 \\
(500.00)\end{array}$ & $\begin{array}{c}14.45 \\
(125.00)\end{array}$ & $\begin{array}{c}102.01 \\
(761.00)\end{array}$ & $\begin{array}{c}25.50 \\
(190.25)\end{array}$ & 1.53 & 0.38 \\
\hline
\end{tabular}

$\mathrm{H}=$ herbicide $\mathrm{I}$. inchange rates in the first half of 2015 were as follows. EUR:SEK $=1.9 .34$, EUR.NOK $=1: 8.65$, EUR:DKK $=1: 7.46$ [50]. ${ }^{2} \mathrm{~F}=$ fungicide, GR $=$ growth regulator, (Sweden), [52] (France), [53,54] (Denmark). 


\subsection{France}

France has introduced a volume tax on pesticides in 2000. First, the tax was introduced as the taxe générale sur les activités polluantes (TGAP), which was valid until 2009. Pesticides were divided into seven taxation categories (based on the eco-toxicological and toxicological properties according to the R-phrases) and the tax had to be paid by the pesticide distributors [55,56]. Category 1 was tax free, category 2 was taxed at $€ 381 / \mathrm{t}$ AS, category 3 at $€ 610 / \mathrm{t}$, category 4 at $€ 838 / \mathrm{t}$, category 5 at $€ 1067 / \mathrm{t}$, category 6 at $€ 1372 / t$, and category 7 was taxed at $€ 1677 / t$ AS. Initially, the values were in Francs, but then converted into Euro at the fixed exchange rate.

In 2009, the TGAP was replaced by a fee on the non-point agricultural pollution (redevance pour pollutions agricoles diffuses). Contrary to the TGAP, only three different pesticide categories are established. Pesticide products being based on mineral AS are charged at the lowest level $(€ 0.9 / \mathrm{kg}$ AS). Pesticides that are considered to be dangerous to the environment are charged at $€ 2 / \mathrm{kg}$ AS. Pesticides that are mutagenic, carcinogenic, or hazardous to reproduction are charged at the highest level, $€ 5.10 / \mathrm{kg}$ AS (Art. L213-10-8 and Art. R213-48-13 Code de l'environnement). The new fee has to be paid at the retail level by the customer. The distributors have to state the fee on the invoice in order to create consciousness for the aim of reducing environmental or health risks of pesticides ([57]; for more information about awareness raising see [5]). The total revenues of the fee amounted up to $€ 60$ million in 2012 and 2013 [58]. Half of these revenues are dedicated to water utility and sewage treatment operators in dependence of the regional pesticide contamination in the water. The remaining tax revenues are invested in other measures of the NAP [57]. However, $50 \%$ of the fee's revenues cannot cover the expenses of the water operators for the cleaning of the pesticide contamination, which are estimated to be between $€ 50-100$ million per year [59]. Additionally, the OECD proposed to internalize further external costs, e.g., costs for biodiversity loss [57]. Therefore, the OECD evaluates the new fee as too low.

The French NAP écophyto 2018 lasts from 2008 until 2018 and aims to reduce the total pesticide usage by 50\% [60]. This NAP was revised in 2015 and the extended NAP écophyto II lasts from 2015 to 2025 still with a reduction goal of 50\% compared to 2015 levels [61]. When assuming that the applied quantity is equal to the sales quantity, the sales quantity serves as a simple pesticide use indicator. This means that under écophyto 2018, a reduction from about 80,000 t AS in 2008 (Figure 1) to 40,000 $\mathrm{t}$ in 2018 has to be achieved. Since the introduction of the tax, the sold amounts decreased sharply to about $66,700 \mathrm{t}$ AS in 2013. Nevertheless, it should be mentioned that the overall pesticide sales in France are quite volatile and that other factors also influence the amount of pesticides applied. Similar to Sweden, the substitution to low dose AS might be relevant, e.g., the market share of copper and sulfur ingredients decreased by $40 \%$ from 2001 to 2004 [55]. For this reason, pesticide volume reduction targets in the NAPs are criticized because less hazardous, high-dose products are replaced by more hazardous, low dose products [62]. The new NAP écophyto II is also of special interest, because a quota system is established and tested (certificats d'économie de produits phytopharmaceutiques), which is, to our knowledge, the first one worldwide. For more information, see [63].

\subsection{Tax Discussions in Other European Countries}

Recently, several other European countries have been discussing about implementing pesticide taxes. The Netherlands, for example, have had several pesticide tax debates which led to the denial of a proposed taxation in the beginning of the millennium [3,64]. Arguments against a fiscal instrument were the relatively high organizational effort [65], the low elasticity of demand, and the higher burdens for domestic producers as well as leakage through import [3,66] (for the elasticity see also [67]). The aims proclaimed in the NAP until 2010 were reached at least partially: large parts of targets regarding environmental load and residue limits in water supply and food have been reached [68]. Looking at the overall sold quantity of pesticides, it can be seen that the sales numbers reduced by almost fifty percent since the 1980s (Figure 1). This decrease was mainly due to stricter obligations for soil fumigants, of which in 1985 10,800 t AS were used and in 2005 only 1,400 t AS [69]. 
Belgium is currently undertaking further research if a tax on pesticides would be useful and constructive [1]. In the 1990s, even a draft for a law was formulated in which selected pesticides should have been charged, but the law did not pass [7]. Meanwhile, stakeholders of the agri-food chain, which includes pesticide producers and distributors, have to finance the Belgian Federal Agency for the Safety of the Food Chain by a yearly fee depending on the number of authorized plant protection products that are sold (Art. 3 Loi relative au financement de l'Agence fédérale pour la Sécurité de la Chaine alimentaire of 9 December 2004 and the periodically amended Royal Decree Arrêté royal fixant les contributions visées à l'article 4 de la loi du 9 décembre 2004 relative au financement de l'Agence fédérale pour la Sécurité de la Chaîne alimentaire of 10 November 2005).

Additionally, in Switzerland, there has been an ongoing debate about pesticide taxes since the 1990s. So far, the Swiss Agency for the Environment, Forests and Landscape argued against pesticide taxes due to the assumed higher effectiveness of other measures (e.g., cross-compliance, registration guidelines, or agri-environmental measures), insufficient knowledge about the tax effects, and too high burdens for Swiss farmers. However, there is some public and political pressure to further promote a reduced application of pesticides. In this context, the necessity of a NAP was analyzed and also the effects of a possible tax are re-analyzed [2].

In Germany, the state minister of agriculture from Schleswig-Holstein proposed to introduce a tax on pesticides in October 2015. The proposal is based on a study of Möckel et al. [4]. The suggestion is a tax scheme which is related to the Norwegian one. A base rate of $€ 20 /$ ha shall be multiplied by a human risk indicator. Additionally, ready-to-use products and pesticides that are on the EU list for substitution shall be levied at higher rates. The tax is proposed to be paid by the industry or the wholesalers. Short-term and long-term reductions of pesticide use are expected to be about $20 \%$ and $35 \%$ in arable farming. The tax would increase the costs of pesticides by $40 \%$ to $50 \%$ per hectare [4].

\section{Analysis of Implementation and Objective Achievement}

While Norway, Denmark, and France established differentiated tax schemes, Sweden sticks to a fixed tax scheme, which has not changed since the 1980s apart from raising the tax rates and abolishing the additional price regulation charge. In Table 5, we present an overview of the different schemes based on the design variations introduced in Table 2. Norway, Denmark, and France use a pesticide risk indicator as well as the amount of AS for the calculation of the differentiated tax. Sweden only uses the amount of AS for the calculation of the flat tax.

Table 5. Overview of the different pesticide tax schemes currently in place.

\begin{tabular}{|c|c|c|c|c|c|}
\hline \multirow{2}{*}{ State } & \multicolumn{2}{|c|}{ Charge } & \multirow{2}{*}{ Imposition Point } & \multicolumn{2}{|c|}{ Use/Refunding of Revenues } \\
\hline & Tax Base & Tax Rate & & Organization & Target \\
\hline \multirow{2}{*}{ Sweden } & Active substances & fix & \multirow{2}{*}{$\begin{array}{c}\text { Industry, } \\
\text { importers/wholesalers }\end{array}$} & \multirow{2}{*}{ Swedish state } & \multirow{2}{*}{ State budget } \\
\hline & All pesticides & $\begin{array}{l}\text { low } / \text { medium tariff, } \\
\text { flat tax }\end{array}$ & & & \\
\hline \multirow[t]{2}{*}{ Norway } & $\begin{array}{l}\text { Active substances, } \\
\text { environmental risk, } \\
\text { human health risk }\end{array}$ & differentiated & \multirow[t]{2}{*}{$\begin{array}{c}\text { Industry, } \\
\text { importer/wholesalers }\end{array}$} & \multirow[t]{2}{*}{ Norwegian state } & \multirow[t]{2}{*}{ State budget } \\
\hline & All pesticides & $\begin{array}{c}\text { low-medium-high } \\
\text { tariffs }\end{array}$ & & & \\
\hline \multirow[t]{2}{*}{ Denmark } & $\begin{array}{l}\text { Active substances, } \\
\text { environmental risk, } \\
\text { human health risk }\end{array}$ & differentiated & \multirow[t]{2}{*}{ Wholesalers/importers } & \multirow[t]{2}{*}{$\begin{array}{c}\text { Danish state—different } \\
\text { ministries }\end{array}$} & \multirow{2}{*}{$\begin{array}{l}\text { State budget, agricultural } \\
\text { fund, green growth } \\
\text { measures, administration }\end{array}$} \\
\hline & All pesticides & $\begin{array}{c}\text { low-medium-high } \\
\text { tariffs }\end{array}$ & & & \\
\hline \multirow[t]{2}{*}{ France } & $\begin{array}{l}\text { Active substances, } \\
\text { human health risk, } \\
\text { (environmental risk) }\end{array}$ & differentiated & \multirow[t]{2}{*}{ Retailers/distributor } & \multirow{2}{*}{$\begin{array}{l}\text { Agricultural and environmental } \\
\text { sector water utility and sewage } \\
\text { treatment operators }\end{array}$} & \multirow[t]{2}{*}{$\begin{array}{l}\text { Measures of the NAP, } \\
\text { cleaning of water }\end{array}$} \\
\hline & All pesticides & low-medium tariffs & & & \\
\hline
\end{tabular}


All of the countries established NAPs in which different objectives for the reduction of pesticides' application or the reduction of pesticides' risks are defined. Building upon the framework derived above, we now analyze whether the different established tax schemes are consistent with the defined goals of the NAPs. The mentioned indicators for the analysis were applied to show the advantages and disadvantages of each scheme. The summarized results of this analysis are presented in Table 6 . Moreover, a comparison of tax levels of selected plant protection products in the four countries is given in Table 4 and serves as decision support for the evaluation.

The main advantage of the Swedish tax scheme is its simplicity. The transaction costs that occur due to the administrative effort of such a scheme are low. Essentially, Sweden could reach its NAP goals by this tax, but the tariffs of the scheme are relatively low and, consequently, not very effective due to the low price elasticity of demand for pesticides. In Sweden, herbicides have the highest share of sold AS. For the period 1950-1989, Gren [70,71] reports a relatively high elasticity between -0.93 and -0.97 for herbicides. Therefore, this is in line with the reductions of sold AS in the 1980s. In the last two decades, however, the elasticity of herbicides seems to be lower, probably due to high reductions in previous years but also due to the increased popularity of conservation tillage (see Section 3.2 and 3.3). Furthermore, no differentiation between pesticides with different loads takes place. This may have led to a reduction of some selected pesticides, which need a high dose, have relatively high price elasticities, or effective substitutes. Nevertheless, the tax increases in the past years (e.g., from SEK 20 to SEK 30/ $\mathrm{kg}$ AS in 2003) have not led to a permanent reduction of the human health and environmental risk indicators, and the dose/ha even increased. For water threshold violations, only ambiguous results can be observed.

Norway has defined two main objectives in the NAP. The established tax scheme has relatively high tariffs on more hazardous pesticides and the tax scheme promotes farmers to use pesticides with a lower environmental load. This has led to a substitution of pesticides, but farmers' reliance on pesticides remains relatively high. Therefore, this scheme is not fully effective in reaching the objective of increasing farmers' compliance with integrated pest management, which has resulted in increased doses being applied, although of less hazardous pesticides. Farmers are burdened by the tax when they substitute to pesticides of the lower risk categories as well. This has a restricting effect to not increase the use of less hazardous pesticides too much. Whether the objective of fewer violations of maximum residue limits can be achieved by such a tax scheme, remains unclear because of difficulties in observing effects that go along or are correlated with the tax introduction. At least, it seems that the tax has not led an increase of water threshold violations, as in most regions and for many AS a reduction can be found [37]. However, other accompanying measures that are defined in the NAP are also relevant for this development. These comprise, for instance, better information techniques or the promotion of improved and more precise spraying techniques. The tax calculation in the Norwegian scheme is sometimes not straightforward, because the SAD is determined based on the recommended pesticide dose in one crop only. In addition, in the calculation it is assumed that the higher the SAD, the lower the risk of a certain pesticide, which is not always the case. This is also revealed by some big tax differences for single products between the Norwegian and the Danish scheme (for example for the herbicides Boxer ${ }^{\circledR}$ and Roundup ${ }^{\circledR}$ Max, Table 4), where the latter system accounts for loads explicitly. 
Table 6. Advantages and disadvantages of existing pesticide taxation schemes. The range of this table is as follows: a "- " is a disadvantage, a " + " is an advantage, and a " \pm " means that no specific effect can be observed.

\begin{tabular}{|c|c|c|c|c|}
\hline \multirow{2}{*}{$\begin{array}{l}\text { Criteria for Analysis } \\
\text { (Section 2) }\end{array}$} & \multicolumn{4}{|c|}{ Country's Tax Scheme } \\
\hline & $\begin{array}{l}\text { Sweden } \\
\text { fix, } \\
\text { SEK } 34 / \mathrm{kg} \text { AS }\end{array}$ & $\begin{array}{l}\text { Norway } \\
\text { differentiated, } \\
7 \text { categories }\end{array}$ & $\begin{array}{l}\text { Denmark } \\
\text { differentiated, } \\
\text { individual tax }\end{array}$ & $\begin{array}{l}\text { France } \\
\text { differentiated, } \\
3 \text { categories }\end{array}$ \\
\hline Main objective of NAP & $\begin{array}{l}\text { NAP 2013-2017 } \\
\text { (1) No violations of residue limits } \\
\text { (2) Reduce pesticides' input }\end{array}$ & $\begin{array}{l}\text { NAP 2010-2014 } \\
\text { (1) 70\% of farmers apply integrated pest } \\
\text { management } \\
\text { (2) No violations of residue limits }\end{array}$ & $\begin{array}{l}\text { NAP 2013-2015 } \\
40 \% \text { load reduction }\end{array}$ & $\begin{array}{l}\text { NAP } 2008-2018 \\
50 \% \text { use reduction from } 2008 \text { to } 2018 \\
\text { and from } 2015 \text { to } 2025\end{array}$ \\
\hline Effectiveness & $\begin{array}{l}\frac{ \pm}{(1,2) \text { in principle possible but tax level }} \\
\text { too low to cause large reduc-tions, no } \\
\text { further long-term reduc-tions after the } \\
\text { last tax increases }\end{array}$ & $\begin{array}{l}\text { (1) } \pm /+ \\
\text { farmers use less hazardous pesti-cides, but } \\
\text { same amount } \\
\text { (2) } \pm \\
\text { farmers use same amount or more pesticides }\end{array}$ & $\begin{array}{l}+ \\
\text { very high taxes on high load pesti-cides } \\
\text { (use reduction) }\end{array}$ & $\begin{array}{l} \pm /+ \\
\text { overall relatively low taxes for all three } \\
\text { categories but nevertheless use } \\
\text { reduction since implementation of tax }\end{array}$ \\
\hline Efficiency & $\begin{array}{l}- \\
(1,2) \text { additional burden for farmers but } \\
\text { no reduction in use }\end{array}$ & $\begin{array}{l}\text { (1) } \pm \\
\text { less hazardous pesticides are relatively } \\
\text { cheap } \\
\text { (2) - } \\
\text { more costs but same amount used }\end{array}$ & $\begin{array}{l} \pm \\
\text { farmers can choose for low taxed } \\
\text { pesticides; some products may } \\
\text { disappear-potential resistance } \\
\text { problems }\end{array}$ & $\begin{array}{l} \pm /+ \\
\text { relatively low additional costs for } \\
\text { farmers but use reduction is achieved }\end{array}$ \\
\hline $\begin{array}{l}\text { Feasibility, } \\
\text { maintainability and } \\
\text { enforceability }\end{array}$ & $\begin{array}{l}+ \\
\text { easy to enforce }\end{array}$ & $\begin{array}{l}-I \pm \\
\text { for some products complicated tax } \\
\text { determination }\end{array}$ & $\begin{array}{l} \pm \\
\text { rather complicated scheme }\end{array}$ & $\begin{array}{l}+ \\
\text { easy to enforce }\end{array}$ \\
\hline $\begin{array}{l}\text { Polluter pays principle, } \\
\text { ability to differentiate } \\
\text { taxation }\end{array}$ & $\begin{array}{l}\text { fix tax scheme, only choice to not pay is } \\
\text { not using pesticides at all }\end{array}$ & $\begin{array}{l}+\perp \pm \\
\text { seven different categories; disputes about } \\
\text { tax calculation }\end{array}$ & $\begin{array}{l}+ \\
\text { individual taxation, almost no tax for } \\
\text { products with low load }\end{array}$ & $\begin{array}{l}-l \pm \\
\text { only three categories; few choices can be } \\
\text { made; revenues for water operators }\end{array}$ \\
\hline $\begin{array}{l}\text { No economic } \\
\text { consequences for farmers, } \\
\text { homogeneity }\end{array}$ & $\begin{array}{l} \pm \\
\text { relatively low tax per ha, especially for } \\
\text { low dose products; only few intensive } \\
\text { pesticide users in Sweden } \\
\text { (few fruit and vegetable farming) }\end{array}$ & $\begin{array}{l}- \\
\text { also when choosing less hazardous } \\
\text { pesticides a tax is charged, probably less } \\
\text { effective plant protection; no return to the } \\
\text { sector }\end{array}$ & $\begin{array}{l} \pm \\
\text { reduction of property tax on } \\
\text { agri-cultural land; revenues returned to } \\
\text { sector; high tax when some products } \\
\text { have to be used, maybe production } \\
\text { losses or changes otherwise, hereby } \\
\text { potential for tax savings compared to } \\
\text { old tax scheme }\end{array}$ & $\begin{array}{l} \pm \\
\text { low tax per ha; tax revenues flow only } \\
\text { partly back into the agricultural sector } \\
\text { (e.g., via environmental programs) }\end{array}$ \\
\hline $\begin{array}{l}\text { Support among farmers, } \\
\text { acceptability }\end{array}$ & $\begin{array}{l}\text { - } \\
\text { despite relatively low tax burden, some } \\
\text { cost increases occur; no tax in most } \\
\text { other European countries }\end{array}$ & $\begin{array}{l}\text { tax burden also when choosing for less } \\
\text { hazardous pesticides; no tax in most other } \\
\text { European countries }\end{array}$ & $\begin{array}{l}- \\
\text { some products may be too expensive to } \\
\text { use, e.g., insecticides; no tax in most } \\
\text { other European countries }\end{array}$ & $\begin{array}{l}\text { - } \\
\text { despite relatively low tax burden, some } \\
\text { cost increases occur; few categories; no } \\
\text { tax in most other European countries }\end{array}$ \\
\hline
\end{tabular}


In the Danish tax scheme, an individual tax is calculated according to the chemical, environmental, and application-specific characteristics of each pesticide. Similar to the Norwegian scheme, more hazardous pesticides are taxed at higher rates. Hereby, the tax differences between single products can be very high (Table 4). Focusing on the taxes per ha of single products, it can be observed that the tax range is much higher compared to the Norwegian scheme. The revenues are, to a large extent, designated for agricultural and environmental measures. The aim of the Danish Government is to decrease the load of pesticides by $40 \%$ until the end of 2015. Such a scheme is in line with the polluter pays principle. However, since some products (often insecticides) are taxed very high, they may disappear from the market (like the above mentioned Cythrin 500 [54]). This also implies potentially large cost increases for some farmers, for example when growing cereals [43]. In contrast, other cropping systems (maize or grassland) are less affected or even have potential to save tax payments, at least when comparing to the old tax system [43]. When the cropping system cannot be changed, critics argue that a consequence could be an increasing use of cheaper pesticides [49] probably without considering the AS' classification to avoid resistances, e.g., according to the chemical classification of the Herbicide/Insecticide/Fungicide Resistance Action Committees.

France has two tier tax schemes to foster a change in the use of pesticides. Firstly, synthetic pesticides are taxed with the regular VAT rate. Pesticides being allowed in organic agriculture are charged with the reduced VAT, giving a comparative advantage to organic farming. Secondly, a three-category differentiated scheme was introduced. On the one hand, pesticides that are mutagenic, carcinogenic, or hazardous to reproduction are taxed relatively high in this scheme. On the other hand, pesticides that are allowed in organic farming and those that are less hazardous are taxed at a lower rate. It appears that this scheme gives incentives for a reduction of products that are levied at the high rate. However, the overall tax that has to be paid by a farmer also depends on the dose per ha of a product. Pesticides of the high tax categories often need a relatively small dose and, therefore, the tax burden per ha might be low (see Table 4 for examples). In contrast, less hazardous, low-levied pesticides get relatively cheaper at a first glance, but these products often have to be applied at a higher dose (e.g., a $20 \%$ copper sulfate product is taxed at $€ 0.18 / \mathrm{kg}$, but their dose is $25 \mathrm{~kg} / \mathrm{ha}$, which results in a tax/ha of $€ 4.5$ ). Thus, in some cases this policy gives incentives to switch to low-dose pesticides. For this reason, the French policy objective of reducing the overall pesticide use is consistent with the French tax but not fully consistent with the targets of a differentiated scheme, which is to reducing the load caused by pesticides. Although the additional costs for farmers are relatively low compared to Norway and Denmark, a use reduction (of AS) is achieved. Even though other measures contributed to this development, the relatively high reduction effects induced by a relatively low tax was confirmed in a simulation study by Jacquet $e t$ al. [72], in which a $20 \%$ reduction is reached by a $16 \%$ ad valorem tax.

\section{Discussion and Conclusions}

Four European countries implemented special taxes in order to control the use of pesticides. Several other countries recently discussed such an instrument. In this article, the tax schemes of Sweden, Norway, Denmark, and France were presented and analyzed. European countries defined different objectives in their NAPs that comprise goals to promote agro-ecological transition, among others, the application reduction, the reduction of the pesticides' load, the increase of integrated pest management, and the non-violation of maximum residue limits. Not all of the established tax schemes were found to be in line with the goals defined in the NAPs. A highly-differentiated tax scheme which leads to a reduction of highly-hazardous pesticides can result in an increase of the application of less hazardous pesticides if suitable alternatives are available. Those pesticides often need a higher dose per hectare so that the overall sold volume is not reduced. If the environmental behavior of pesticides is not included adequately in the tax calculation, those pesticides can also be transported into bodies of water. Thus, violations of threshold values can still occur, although shifted to less hazardous products. Nevertheless, it can be stated that when the reduction objective is well defined and the chosen indicators are well developed, differentiated taxes can be an effective environmental policy 
instrument in the long-term and a contribution to integrated pest management. However, in order to reduce the reliance on pesticides significantly (and not making them dependent on less hazardous ones), a tax scheme has to go hand in hand with accompanying measures promoting preventive measures of integrated pest management. In the short-term, no environmental and human health benefits will be observed due to large hoarding activities by retailers and farmers (peaks in Figures 1-3), and low price elasticities $[67,73]$. So far, no clear indication could be found in the literature whether a tax is efficient or not: for example, Reus et al. [11] find no notable or only a moderate effectiveness, whereas Oskam et al. [5] and Falconer [12] notice a high/positive effectiveness. Our analysis shows that taxes are a potentially effective instrument, but appropriate economic, political, and environmental circumstances have to be given.

The identification of the effects of taxes is hampered, because often many policy measures are introduced at the same time and farmers may change their behavior so that versatile effects occur. Many of those alternative measures are effective as well. Examples are regulatory measures, increasing information, persuasion and awareness, technological or institutional change, arrangements, or other economic instruments (see [5], for a list of measures). For instance, in the Netherlands, banning-alike permissions for soil fumigants led to a $50 \%$ reduction of total pesticides sold. Additional insights from micro-studies are, therefore, needed to evaluate the efficiency of pesticide taxes, also accounting for accompanying measures. In addition, an enhancement of the indicators is necessary to better reflect the use and risks of different pesticides on farms. Ideally, as proposed by Benbrook et al. [74], such indicators should consist of both a pesticide use and a pesticide risk indicator, so that both the exposure and the toxicity are covered. This is, for example, done in the model SYNOPS [75], but also in the calculation of the tax in Norway and Denmark. The feasibility, maintainability, and enforceability should be unproblematic in developed countries with well-established institutions and modern pesticide application techniques. Moreover, all countries implemented taxes on pesticide products at the industry or distributor level and not on pesticide use at the farm level. Problems occur sometimes in the calculation of differentiated tax schemes, because, although they are often based on a pesticide risk indicator, some political judgments have to be made by the authorities.

Taxes can have different targets. For example, the goal can be to generate revenues (either for the sake of general revenues or according to the polluter pays principle) or to create incentives to use fewer or less hazardous pesticides. It is also possible to combine both targets, but sometimes the target pursued by a government remains unclear. The Danish scheme follows the polluter pays principle since every pesticide is taxed by its individual load. The French tax scheme follows both objectives, but by only differentiating three categories, the polluter pays principle is not adequately followed. The Swedish tax does not consider the polluter pays principle. Notwithstanding this, also due to many accompanying measures, decreases of the pesticide risk indicator in the beginning of the 1990s could be observed. While the general structure of the tax is still in line with the objective of the NAPs, the tax seems not in line with current knowledge on the design of pesticide taxation and the developments in other countries. At first sight, the economic consequences for farmers are negative in most schemes since a higher price has to be paid for the products but the pesticide use reductions are small. This is due to the low price elasticity of demand for pesticides, which also limits the effectiveness of taxes with respect to pesticide use reductions. From a polluter pays-point of view, this is in line with policy targets and promotes transition to integrated agricultural systems that are less dependent on chemical inputs, albeit a change towards more organic farming could not be observed in the wake of tax introductions or increases-according to Eurostat data [76]. Additionally, no clear pattern could be observed if the transition to more organic farming influences the pesticide use statistics. Negative economic consequences for farmers might be reduced if tax revenues are fed back into the sector, as it is the case in Denmark and partly in France. Hereby, spending the tax revenues for explicit environmental measures (biocontrol, buffer zones, etc.) could generate a leverage effect on the effectiveness of tax schemes. In differentiated tax schemes, less hazardous pesticides are also taxed. From an incentive creating-point of view, however, a differentiated tax scheme should 
offer untaxed or very low taxed, less hazardous pesticides, creating incentives to switch to these products. Nevertheless, the applicability of the polluter pays principle is limited due to the difficulties of calculating all (external) costs and benefits of a pesticide application.

Supplementary Materials: The supplementary materials are available online at www.mdpi.com/2071-1050/ $8 / 4 / 378 /$ s1

Acknowledgments: The authors thank the Swiss Federal Office for Agriculture for funding and supporting this research. We also thank Anne Strøm Prestvik of the Norwegian Institute of Bioeconomy Research for providing information about the Norwegian pesticide tax scheme. Moreover, we would like to thank two anonymous reviewers for constructive comments and suggestions on an earlier draft of this paper.

Author Contributions: Thomas Böcker and Robert Finger conceived and performed the study and wrote the manuscript.

Conflicts of Interest: The authors declare no conflict of interest.

\section{Abbreviations}

The following abbreviations are used in this manuscript:

$\begin{array}{ll}\text { AS } & \text { active substance } \\ \text { DKK } & \text { Danish krone } \\ \text { ha } & \text { hectare } \\ \text { NAP } & \text { national action plan } \\ \text { NOK } & \text { Norwegian krone } \\ \text { SAD } & \text { standard area dose } \\ \text { SEK } & \text { Swedish krona } \\ \text { TGAP } & \text { taxe générale sur les activités polluantes } \\ \text { VAT } & \text { value added tax }\end{array}$

\section{References}

1. ARCADIS Belgium. Vergroening van de Fiscaliteit. Bijlage 2: Groslijst Vergroeningsopties; ARCADIS Belgium nv/sa: Brussels, Belgium, 2014; pp. 42-46.

2. Federal Department of Economic Affairs, Education and Research (EAER). Bedarfsabklärung Eines Aktionsplans zur Risikoreduktion und Nachhaltigen Anwendung von Pflanzenschutzmitteln-Bericht in Erfüllung des Postulates 12.3299 von Frau Nationalrätin Tiana Angelina Moser vom 16. März 2012; Eidgenössisches Departement für Wirtschaft, Bildung und Forschung WBF: Berne, Switzerland, 2014.

3. Hof, B.; Koopmans, C.; Rougoor, W.; van der Voort, J. Effecten en Vormgeving van een Heffing op Gewasbeschermingsmiddelen; Rapport nr. 2013-39; SEO Economisch Onderzoek: Amsterdam, The Netherlands, 2013.

4. Möckel, S.; Gawel, E.; Kästner, M.; Liess, M.; Knillmann, S.; Bretschneider, W. Einführung einer Abgabe auf Pflanzenschutzmittel in Deutschland. In Studien zu Umweltökonomie und Umweltpolitik; Gawel, E., Ed.; Duncker \& Humblot: Berlin, Germany, 2015; Volume 10, pp. 1-305.

5. Oskam, A.J.; Vijftigschild, R.A.N.; Graveland, C. Additional EU Policy Instruments for Plant Protection Products. A Report within the Second Phase of the Programme: Possibilities for Future EC Environmental Policy on Plant Protection Products; Wageningen Agricultural University: Wageningen, The Netherlands, 1997.

6. Hoevenagel, R.; van Noort, E.; de Kok, R. Study on a European Union wide Regulatory Framework for Levies on Pesticides; EIM Small Business Research and Consultancy, Haskoning: Zoetermeer, The Netherlands, 1999.

7. Ecotec Research \& Consulting; Centre for Social Science Research on the Environment (CESAM); Centre for Agriculture and Environment (CLM); University of Gothenburg; University College Dublin (UCD); Institute for European Environmental Policy (IEEP). Study on the Economic and Environmental Implications of the Use of Environmental Taxes and Charges in the European Union and its Member States; Ecotec Research \& Consulting: Brussels, Belgium; Birmingham, UK, 2001.

8. Gregoriou, P.; Manuneas, T.; Pashardes, P. Agricultural Support Policies and Optimum Tax and Levy Scheme for Pesticide Use in Farm Production; Economic Analysis Papers No. 03-09; Economics Research Centre, University of Cyprus: Nicosia, Cyprus, 2009. 
9. Skevas, T.; Oude Lansink, A.G.J.M.; Stefanou, S.E. Designing the emerging EU pesticide policy: A literature review. NJAS Wagening. J. Life Sci. 2013, 64-65, 95-103. [CrossRef]

10. Lefebvre, M.; Langrell, S.R.H.; Gomez-y-Paloma, S. Incentives and policies for integrated pest management in Europe: A review. Agron. Sustain. Dev. 2015, 35, 27-45. [CrossRef]

11. Reus, J.A.W.A.; Weckseler, H.J.; Pak, G.A. Towards a Future EC Pesticide Policy-An Inventory of Risks of Pesticide Use, Possible Solutions and Policy Instruments; Centre for Agriculture and Environment (CLM): Utrecht, The Netherlands, 1994.

12. Falconer, K.E. Managing diffuse environmental contamination from agricultural pesticides: An economic perspective on issues and policy options, with particular reference to Europe. Agric. Ecosyst. Environ. 1998, 69, 37-54. [CrossRef]

13. Popp, J.; Pető, K.; Nagy, J. Pesticide productivity and food security. A review. Agron. Sustain. Dev. 2013, 33, 243-255. [CrossRef]

14. Zilberman, D.; Millock, K. Financial incentives and pesticide use. Food Policy 1997, 22, 133-144. [CrossRef]

15. Eurostat. A Common Methodology for the Collection of Pesticide Usage Statistics within Agriculture and Horticulture; Office for Official Publications of the European Communities: Luxembourg City, Luxembourg, 2008.

16. Van Bol, V.; Claeys, S.; Debognie, P.; Godfriaux, J.; Pussemier, L.; Steurbaut, W.; Maraite, H. Pesticide Indicators. Pestic. Outlook 2003, 14, 159-163. [CrossRef]

17. European Commission. VAT Rates Applied in the Member States of the European Union-Situation at 1st September 2015. Available online: http:/ / ec.europa.eu/taxation_customs/resources/documents/taxation/ vat/how_vat_works/rates/vat_rates_en.pdf (accessed on 7 January 2016).

18. Organisation for Economic Co-operation and Development (OECD). OECD Environmental Performance Reviews: Finland; OECD Publishing: Paris, France, 2009.

19. Notisum AB. Rättsnätet—Lag (1984:410) om Skatt på Bekämpningsmedel; Sweden, 2015. Available online: http://www.notisum.se/rnp/sls/lag/..\%5Cfakta\%5Ca9840410.htm (accessed on 7 January 2016).

20. Landsbygdsdepartementet-Ministry of Rural Affairs. National Action Plan for the Sustainable Use of Plant Protection Products for the Period 2013-2017; Landsbygdsdepartementet: Stockholm, Sweden, 2013.

21. Larsson, M.; Boström, G.; Gönczi, M.; Kreuger, J. Kemiska Bekämpningsmedel i Grundvatten 1986-2014Sammanställning av Resultat och Trender i Sverige under tre Decennier, Samt Internationella Utblickar; Havs och Vattenmyndigheten Rapport 2014:15, CKB Rapport 2014:1; Havs och Vattenmyndigheten, KompetensCentrum för Kemiska Bekämpningsmedel (CKB): Uppsala, Sweden, 2014.

22. Spikkerud, E. Taxes as a tool to reduce health and environmental risk from pesticide use in Norway. In Evaluating Agri-Environmental Policies: Design, Practice and Results; OECD, Ed.; OECD Publishing: Paris, France, 2005; pp. 281-290.

23. Eurostat. Agri-Environmental Indicators-Farm Management-Pesticide Sales; Luxembourg, 2016. Available online: http:/ /ec.europa.eu/eurostat/data/database (accessed on 12 April 2016).

24. Bergkvist, P. Pesticide Risk Indicators at National Level and Farm Level-A Swedish Approach; Nr 6/04; Kemikalieinspektionen: Sundbyberg, Sweden, 2004.

25. Statskontoret. Effekter på Priset för Handelsgödsel när Skatten på Kväve i Handelsgödsel Avskaffas—en Delrapport; Regeringen-Jordbruksdepartementet: Stockholm, Sweden, 2010.

26. Baeumer, K. Allgemeiner Pflanzenbau, 3rd ed.; UTB für Wissenschaft-Verlag Eugen Ulmer: Stuttgart, Germany, 1992.

27. Naturvårdsverket. Dataunderlag_Växtskyddsmedel—Dataunderlag-Växtskyddsmedel; 2016. Available online: http:/ / www.miljomal.se/Miljomalen/Alla-indikatorer/Indikatorsida/Dataunderlag-for-indikator/ ?iid=139\&pl=1\&t=Land\&l=SE (accessed on 24 March 2016).

28. Spikkerud, E.; Haraldsen, T.; Abdellaue, A.; Holmen, M.T. Guidelines for a Banded Pesticide Tax Scheme, Differentiated According to Human Health and Environmental Risks; Norwegian Food Safety Authority-National Centre of Plants and Vegetable Foods: Brumunddal, Norway, 2005.

29. Mattilsynet-Norwegian Food Safety Authority. Miljøavgift for Plantevernmidler (Februar 2014); 2014. Available online: http://www.mattilsynet.no/language/english/plants/plant_protection_products / taxes_for_plant_protection_products.17427 (accessed on 7 January 2016).

30. Strøm Prestvik, A.; Netland, J.; Hovland, I. Evaluering av Avgiftssystemet for Plantevernmidler i Norge; 2013. Available online: http://www.mattilsynet.no/planter_og_dyrking/plantevernmidler/mattilsynet_evaluerer _avgiftssystemet_for_plantevernmidler.12116 (accessed on 7 January 2016). 
31. Stortingets administrasjon. Statsbudsjettet for 2015-Saldert Budsjett Vedtatt i Stortinget Høsten 2014; Stortingets Administrasjon-Konstitusjonell Avdeling: Oslo, Norway, 2015.

32. Gianessi, L.; Rury, K.; Rinkus, A. An evaluation of pesticide use reduction policies in Scandinavia. Outlooks Pest Manag. 2009, 20,1-7. [CrossRef]

33. Landbruksdepartementet-Ministry of Agriculture. Action Plan on Reducing Risk Connected to the Use of Pesticides (2004-2008)); Publication number M—0727 E; Landbruksdepartementet, 2004. Available online: https://www.regjeringen.no/globalassets/upload/lmd/vedlegg/brosjyrer_veiledere_rapporter/action _plan_on_reducing_risk_connected_to_the_use_of_pesticides_2004_2008.pdf (accessed on 7 January 2016).

34. Norwegian Agricultural Inspection Service. OECD Survey of National Pesticide Risk Indicators, 1999-2000. Available online: http://www.oecd.org/chemicalsafety/pesticides-biocides/1934217.pdf (accessed on 7 January 2016).

35. Landbruks- og matdepartementet-Ministry of Agriculture and Food. Handlingsplan for Redusert Risiko ved Bruk av Plantevernmidler (2010-2014)); National Action Plan from 18 September 2009. Available online: https://www.regjeringen.no/globalassets/upload/lmd/vedlegg/handlingsplan_plantervern_2010_2014.pdf (accessed on 7 January 2016).

36. Mattilsynet-Norwegian Food Safety Authority. National Monitoring Program for Residues of Pesticides in Food, Melding nr. 4/2013, nr. 5/2013, nr. 7/2014; Mattilsynet: Brumunddal, Norway, 2014; Available online: http://www.mattilsynet.no/language/english/sok/?search=plantevernmidler+ (accessed on 7 January 2016)

37. Bechmann, M.; Stenrød, M.; Pengerud, A.; Grønsten, H.A.; Deelstra, J.; Eggestad, H.O.; Hauken, M. Erosjon og tap av Næringsstoffer og Plantevernmidler fra Jordbruksdominerte Nedbørfelt-Sammendragsrapport fra Program for Jord- og Vannovervåking i Landbruket (JOVA) for 1992-2013; Rapport Volume 9; Bioforsk: Ås, Norway, 2014. (In Norwegian)

38. Øgaard, A.F.; Skaalsveen, K. Resultater fra Program for Jord-og Vannovervåking i Landbruket (JOVA) for 1992-2014; NIBIO—Norsk Institutt for Bioøkonomi: Ås, Norway, 2015.

39. Strøm Prestvik, A.; NIBIO—Norwegian Institute of Bioeconomy Research, Ås, Akershus, Norway. Personal communication, 2015.

40. Miljøministeriet-Ministry of Environment. The Agricultural Pesticide Load in Denmark 2007-2010; Environmental Review No. 2/2012; Miljøministeriet: Copenhagen, Denmark, 2012.

41. Pedersen, A.B.; Nielsen, H.Ø.; Andersen, M.S. The Danish pesticide tax. In Use of Economic Instruments in Water Policy—Insights from International Experience; Lago, M., Mysiak, J., Gómez, C.M., Delacámara, G., Maziotis, A., Eds.; Springer International Publishing: Cham, Switzerland, 2015; pp. 73-87.

42. Miljøministeriet-Ministry of Environment. Background and Content of the New Pesticide Tax. In Proceedings of the International Seminar on a New Danish Pesticide Tax, Danish Environmental Protection Agency, Copenhagen, Denmark, 30 May 2013.

43. Hansen, L.F. New Pesticide Tax and Indicator in Denmark-National Action Plans. In Proceedings of the International Seminar on a New Danish Pesticide Tax, Danish Environmental Protection Agency, Copenhagen, Denmark, 30 May 2013.

44. Schou, J.S.; Streibig, J.C. Pesticide taxes in Scandinavia. Pestic. Outlook 1999, 10, 227-229.

45. Skatteministeriet. Afgifter-Provenuet af Afgifter og Moms 2009-2016; Denmark, 2015. Available online: http://www.skm.dk/skattetal/statistik/provenuoversigter/afgifter-provenuet-af-afgifter-og-moms-2009-2016 (accessed on 15 February 2016).

46. Natur- og Landbrugskommissionen. Natur-og Landbrugskommissionens Statusreport: Bilag 10_Pesticidafgifter Opkrævning og Anvendelse; Natur- og Landbrugskommissionen: Copenhagen, Denmark, 2012.

47. Miljøministeriet, Ministeriet for Fødevarer, Landbrug og Fiskeri-Ministry of the Environment, Ministry of Food, Agriculture and Fisheries. Protect Water, Nature and Human Health—Pesticide Strategy 2013-2015; Danish Ministry of the Environment Information Centre: Copenhagen, Denmark, 2013.

48. Jørgensen, L.N.; Ørum, J.E. Farmers' Possibilities for Shifting to Pesticides with Lower Load and Manage Resistance-Fungicides and Insecticides. In International Seminar on a New Danish Pesticide Tax, Danish Environmental Protection Agency, Copenhagen, Denmark, 30 May 2013.

49. Nørring, N.P. Pesticide Taxation: Does It Work? In International Seminar on a New Danish Pesticide Tax, Danish Environmental Protection Agency, Copenhagen, Denmark, 30 May 2013.

50. Eurostat. Exchange Rates-Bilateral Exchange Rates-Euro/ECU Exchange Rates; Luxembourg, 2015. Available online: http:/ /ec.europa.eu/eurostat/data/database (accessed on 12 April 2016). 
51. Kemikalieinspektionen (KEMI). Databaser-Bekämpningsmedelsregistret, Sundbyberg, Sweden, 2015. Available online: http:/ / webapps.kemi.se/BkmRegistret/Kemi.Spider.Web.External/ (accessed on 7 January 2016).

52. Ministère de l'Écologie, du Développement Durable et de l'Énergie (MEDDE). Montant par Produit Pour l'année 2015. Redevance Phyto \& Traçabilité des Ventes; France, 2015. Available online: http://redevancephyto.developpement-durable.gouv.fr/distributeur/montantparproduit (accessed on 7 January 2016).

53. Miljø- og Fødevareministeriet. Afgift på Sprøjtemidler-Hent Listen over Afgifter pr. 12. Februar 2015; Copenhagen, Denmark, 2015. Available online: http://mst.dk/virksomhed-myndighed/bekaempelsesmidler/ sproejtemidler/bruger/pesticidafgift/ (accessed on 7 January 2016).

54. SEGES P/S. Middeldatabasen; Aarhus, Denmark, 2015. Available online: https://www.middeldatabasen.dk/ default.asp (accessed on 7 January 2016).

55. Aubertot, J.-N.; Barbier, J.-M.; Carpentier, A.; Gril, J.-J.; Guichard, L.; Lucas, P.; Savary, S.; Voltz, M.; Savini, I. Pesticides, Agriculture and the Environment-Reducing the Use of Pesticides and Limiting Their Environmental Impact; INRA and Cemagref: Rennes and Lyon, France, 2005.

56. Ministère de l'Agriculture et de la Pêche (MAP). Avis Relatif à la Liste des Substances Dangereuses du Plan Interministériel de Réduction des Risques Liés aux Pesticides. Journal Officiel de la République Française, NOR: AGRG0602464V, 2016. Available online: http://www.legifrance.gouv.fr/ jo_pdf.do?id=JORFTEXT000000423707 (accessed on 7 January 2016). (In French).

57. Organisation for Economic Co-operation and Development (OECD). OECD Economic Surveys: France 2011; OECD Publishing: Paris, France, 2011.

58. République Française. Agences de l'eau-Annexe au Projet de loi de Finances Pour 2015; 2014. Available online: http://www.performance-publique.budget.gouv.fr/sites/performance_publique/files/farandole/ ressources/2015/pap/pdf/jaunes/Jaune2015_agences_eau.pdf (accessed on 7 January 2016).

59. Bommelaer, O.; Devaux, J. Le Financement de la Gestion des Ressources en eau en France (Actualisation de Janvier 2012); Études \& Documents Nr. 62; Commissariat Général au Développement Durable: La Défense, France, 2012. (In French)

60. Ministère de l'Agriculture et de la Pêche (MAP). Écophyto 2018; République Française: Paris, France, 2008. (In French)

61. Ministère de l'Agriculture, de l'Agroalimentaire et de la Forêt (MAAF); Ministère de l'Écologie, du Développement durable et de l'Énergie (MEDDE). Plan Écophyto II; République Française: Paris, France, 2015.

62. Barzman, M.; Dachbrodt-Saaydeh, S. Comparative analysis of pesticide action plans in five European countries. Pest Manag. Sci. 2011, 67, 1481-1485. [CrossRef] [PubMed]

63. Belassen, V. Les Certificats D'économie de Produits Phytosanitaires: Quelle Contrainte et Pour qui; Working Paper 2015/4; CESAER INRA—Centre d'Economie et Sociologie appliquées à l'Agriculture et aux Espaces Ruraux: Dijon, France, 2015. (In French)

64. Tweede Kamer. Fiscaliteit, landbouw- en Natuurbeleid, Kamerstuk 28207 nr. 3, Lijst van Vragen en Antwoorden, Vergaderjaar 2002-2003, Den Haag, The Netherlands, 2003. Available online: https:/ / zoek. officielebekendmakingen.nl/dossier /28207/ kst-28207-3?resultIndex=12\&sorttype=1\&sortorder=4 (accessed on 7 January 2016).

65. Tweede Kamer. Fiscaliteit, Landbouw- en Natuurbeleid, Kamerstuk 28207, nr. 5, Verslag van een Notaoverleg, Vergaderjaar 2003-2004, Den Haag, The Netherlands, 2003. Available online: https:/ / zoek. officielebekendmakingen.nl/dossier /28207/kst-28207-5?resultIndex=10\&sorttype=1\&sortorder=4 (accessed on 7 January 2016).

66. Boon, P.E.; van Donkersgoed, G.; Noordam, M.; te Biesebeek, J.D.; van de Ven-van den Hoogen, B.M.; van Klaveren, J.D. Evaluatie van de nota Duurzame gewasbescherming-Deelrapport Voedselveiligheid; RIVM Rapport 320038001/2012; Rijksinstituut voor Volksgezondheid en Milieu: Bilthoven, The Netherlands, 2012.

67. Skevas, T.; Stefanou, S.E.; Oude Lansink, A. Can economic incentives encourage actual reductions in pesticide use and environmental spillovers? Agric. Econ. 2012, 43, 267-276. [CrossRef]

68. Van Eerdt, M.; van Dam, J.; Tiktak, A.; Vonk, M.; Wortelboer, R.; van Zeijts, H. Evaluatie van de Nota Duurzame Gewasbescherming; PBL-Publicatienummer 500158001; Planbureau voor de Leefomgeving: Den Haag, The Netherlands, 2012. 
69. Centraal Bureau voor de Statistiek (CBS); Planbureau voor de Leefomgeving (PBL); Wageningen UR. Afzet van Chemische Gewasbeschermingsmiddelen in de Land- en Tuinbouw, 1985-2013. Available online: http://www.compendiumvoordeleefomgeving.nl/indicatoren/nl0015-Afzet-gewasbeschermingsmiddelenin-de-land-en-tuinbouw.html?i=11-61 (accessed on 7 January 2016).

70. Gren, I.-M. Cost efficient pesticide reductions: A study of Sweden. Environ. Resour. Econ. 1994, 4, $279-293$. [CrossRef]

71. Gren, I.-M. Regulating the farmers' use of pesticides in Sweden. In Economic Incentives and Environmental Policies-Principles and Practice; Opschoor, H., Turner, K., Eds.; Kluwer Academic Publishers: Dordrecht, The Netherlands, 1994; pp. 153-173.

72. Jacquet, F.; Butault, J.P.; Guichard, L. An economic analysis of the possibility of reducing pesticides in French field crops. Ecol. Econ. 2011, 70, 1638-1648. [CrossRef]

73. Falconer, K.; Hodge, I. Using economic incentives for pesticide usage reductions: Responsiveness to input taxation and agricultural systems. Agric. Syst. 2000, 63, 175-194. [CrossRef]

74. Benbrook, C.M.; Sexson, D.L.; Wyman, J.A.; Stevenson, W.R.; Lynch, S.; Wallendal, J.; Diercks, S.; van Haren, R.; Granadino, C.A. Developing a pesticide risk assessment tool to monitor progress in reducing reliance on high-risk pesticides. Am. J. Potato Res. 2002, 79, 183-199. [CrossRef]

75. Gutsche, V.; Strassemeyer, J. SYNOPS-A model to assess the environmental risk potential of pesticides. J. für Kulturpflanzen. 2007, 59, 197-210.

76. Eurostat. Agriculture-Organic Farming-Number of Certified Registered Organic Operators by Type of Operators; Luxembourg, 2016. Available online: http:/ / ec.europa.eu/eurostat/data/database (accessed on 12 April 2016).

(C) 2016 by the authors; licensee MDPI, Basel, Switzerland. This article is an open access article distributed under the terms and conditions of the Creative Commons Attribution (CC-BY) license (http:/ / creativecommons.org/licenses/by/4.0/). 